\title{
Pharmacological Efficacy of Ginseng against Respiratory Tract Infections
}

\author{
Abdulrhman Alsayari ${ }^{1} \mathbb{D}$, Abdullatif Bin Muhsinah ${ }^{1} \mathbb{D}$, Dalia Almaghaslah ${ }^{2} \mathbb{D}$, Sivakumar Annadurai ${ }^{1}$ \\ and Shadma Wahab ${ }^{1, *}$ \\ 1 Department of Pharmacognosy, College of Pharmacy, King Khalid University, Abha 61421, Saudi Arabia; \\ alsayari@kku.edu.sa (A.A.); ajmohsnah@kku.edu.sa (A.B.M.); sannadurai@kku.edu.sa (S.A.) \\ 2 Department of Clinical Pharmacy, College of Pharmacy, King Khalid University, Abha 61421, Saudi Arabia; \\ damoazle@kku.edu.sa \\ * Correspondence: sabdulwahab@kku.edu.sa or shad.nnp@gmail.com
}

Citation: Alsayari, A.; Muhsinah, A.B.; Almaghaslah, D.; Annadurai, S.; Wahab, S. Pharmacological Efficacy of Ginseng against Respiratory Tract Infections. Molecules 2021, 26, 4095. https://doi.org/10.3390/molecules 26134095

Academic Editor: Dana Maria Copolovici

Received: 7 May 2021

Accepted: 2 July 2021

Published: 5 July 2021

Publisher's Note: MDPI stays neutral with regard to jurisdictional claims in published maps and institutional affiliations.

Copyright: (c) 2021 by the authors. Licensee MDPI, Basel, Switzerland. This article is an open access article distributed under the terms and conditions of the Creative Commons Attribution (CC BY) license (https:// creativecommons.org/licenses/by/ $4.0 /)$.
Abstract: Respiratory tract infections are underestimated, as they are mild and generally not incapacitating. In clinical medicine, however, these infections are considered a prevalent problem. By 2030, the third most comprehensive reason for death worldwide will be chronic obstructive pulmonary disease (COPD), according to the World Health Organization. The current arsenal of anti-inflammatory drugs shows little or no benefits against COPD. For thousands of years, herbal drugs have been used to cure numerous illnesses; they exhibit promising results and enhance physical performance. Ginseng is one such herbal medicine, known to alleviate pro-inflammatory chemokines and cytokines (IL-2, IL-4, IFN- $\gamma$, TNF- $\alpha$, IL-5, IL-6, IL-8) formed by macrophages and epithelial cells. Furthermore, the mechanisms of action of ginsenoside are still not fully understood. Various clinical trials of ginseng have exhibited a reduction of repeated colds and the flu. In this review, ginseng's structural features, the pathogenicity of microbial infections, and the immunomodulatory, antiviral, and anti-bacterial effects of ginseng were discussed. The focus was on the latest animal studies and human clinical trials that corroborate ginseng's role as a therapy for treating respiratory tract infections. The article concluded with future directions and significant challenges. This review would be a valuable addition to the knowledge base for researchers in understanding the promising role of ginseng in treating respiratory tract infections. Further analysis needs to be re-focused on clinical trials to study ginseng's efficacy and safety in treating pathogenic infections and in determining ginseng-drug interactions.

Keywords: ginseng; respiratory tract infection; immuno-modulatory effects; cytokines; antiviral activity; antibacterial activity

\section{Introduction}

According to MedlinePlus, lung disease is considered any problem in the lungs that prevents them from working correctly. The standard classifications of lung diseases are restrictive, obstructive, or vascular. WHO estimates that the third most comprehensive reason for death worldwide by 2030 may be chronic obstructive pulmonary disease (COPD). The problem of respiratory infections is underestimated, as these are generally mild and not incapacitating. The majority of infections are caused by cosmopolitan agents, while geographical or tropical infections are rare.

In clinical medicine, respiratory tract infections (RTIs) are considered prevalent and pose vital problems. Antibiotics are commonly prescribed to treat and manage respiratory infections, even though published literature indicates that they rarely benefit patients. Nasal pharyngitis, acute bronchitis, and non-specific upper respiratory tract infections are caused by respiratory viruses [1]. Several different types of viruses may infect the respiratory tract; these include the adenovirus, rhinovirus, parainfluenza virus, coronavirus, 
enterovirus, respiratory syncytial virus, and influenza virus. SARS-CoV, SARS-CoV-2, and MERS-CoV are also agents of respiratory infections.

The risk of RTIs is increasing in children and in adults with immune deficiencies due to indoor and outdoor air pollutants which impair their lungs [2,3]. Other causes of the rapid spread of RTIs are the cough and sneeze of an infected person. RTIs are divided into upper respiratory tract infections (throat and sinuses) and lower respiratory tract infections (airways and lungs). The root cause of limitations to progressive airflow is the excessive inflammatory response to breath irritants. The inflammation is due to neutrophils, macrophages, and activated T-lymphocytes (cytotoxic T-cells [Tc1] and helper T-cells [Th1]), leading to emphysema, airway fibrosis, mucus hypersecretion, and oxidative stress. To date, the medical practitioners' primary focus has been on the antagonists that inhibit the recruitment and activation of inflammatory cells. However, none of the currently available anti-inflammatory medications provide satisfactory relief to COPD patients and may end up producing side effects; therefore, safe, effective medications for inhibiting inflammatory response are needed to treat COPD [4]. An overview of respiratory tract infections caused by bacteria or viruses is depicted in Figure 1.

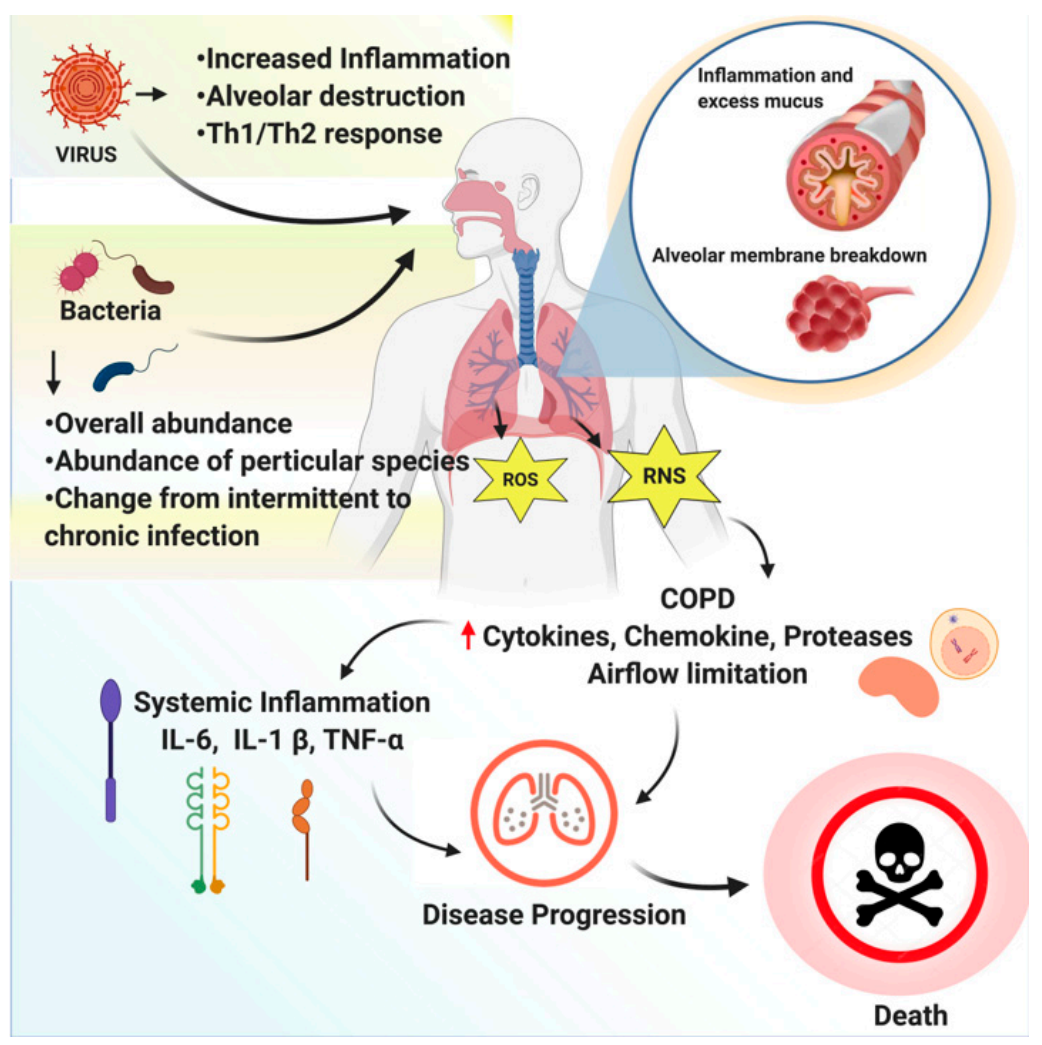

Figure 1. An overview of respiratory tract infections caused by bacteria and viruses. Respiratory pathogens increase the chance of intermittent to chronic lung infection by increasing inflammation and alveolar destruction. Generation of reactive oxygen species (ROS) and reactive nitrogen species (RNS) leads to increase cytokines, chemokines, protease, and limitation of airflow that induce the severity and progression of COPD, systemic inflammation, and lung disease progression and decrease patient survival.

For thousands of years, herbal drugs have been used to cure numerous illnesses and to improve overall well-being. Among the commonly used herbal medicines, Panax ginseng C. A. Meyer is a recognized herb cultivated mainly in Korea, China, and the U.S.A. It is used worldwide to treat many diseases. The principal ingredients of ginseng are amino acids, proteins, flavonoids, volatile oils, and polysaccharides [5,6]. Various forms of ginseng 
are available, including fresh, dried, boiled, and red ginseng, as well as extracts. These extracts are marketed as dietary, nutritional, and wellness supplements [7-9].

In the past 50 years, numerous clinical and preclinical research studies have been conducted on ginseng $[10,11]$. These have shown that $P$. ginseng improves lung function and overall quality of life compared with pharmacotherapy alone. However, few studies have explored $P$. ginseng against COPD and other associated disorders, such as chronic bronchitis, but these have shown encouraging results [12-15]. These studies have resulted in a better understanding of ginseng's phytocomponents, their possible mechanism of action, pharmacological properties, and toxicological profile. The key active component of ginseng was first established by Shibata et al. based on their aglycone moieties as dammarane-type triterpene saponins and ginsenosides. These can be further categorized into 20(S)-protopanaxatriol (ginsenosides Re, Rg1, Rg2, and Rh1) and 20(S)-protopanaxadiol (ginsenosides $\mathrm{Rb} 1, \mathrm{Rb} 2, \mathrm{Rb} 3, \mathrm{Rc}$, and $\mathrm{Rd}$ ) class [16]. The active constituents' composition and quality depend on various factors, such as the method of cultivation, harvesting season, preservation method, age, and part of the plant used [17]. Naturally occurring ginsenosides have been shown to possess antifungal and antimicrobial properties. Their bitter taste makes them a suitable antifeedant [17-20].

Human immune cells were treated with various ginseng extracts by Lau et al. Seven ginsenosides were reported that could specifically suppress production of the inflammatory gene CXCL-10. The observed anti-inflammatory role of ginseng was attributed to the combined effects of these ginsenosides targeting different immunological activity levels, thereby contributing to ginseng's various actions in humans [21]. Ginseng suppresses a portion of the TNF- $\alpha$-inducible cytokines and signaling proteins in promonocytic cells and exerts its anti-inflammatory activity by targeting different levels of the TNF- $\alpha$ signaling pathways [22]. Studies conducted on animals have shown that ginseng provokes a robust immune response that protects against bacterial and viral infections [23-25]. Ginseng induces the dissolution and dispersion of mature biofilms and also represses biofilm development. The role of ginseng and its main active constituents in reducing the risk and continuation of flu and colds has been reported in several studies, including clinical trials [26]. Various controlled clinical trials have been conducted to study ginseng's efficacy in COPD, but these trials were small and biased. Therefore, rigorously designed studies are needed [7].

Herein, we reviewed the available literature on ginseng's active components and their role against respiratory pathogens. The present review summarized ginseng's possible modes of action, clinical evidence, and consequences as a therapeutic agent against respiratory infections. Interventional clinical trials are needed to evaluate ginseng's properties, including immunomodulatory, anti-inflammatory, antimicrobial, and antiviral activities.

\section{The Methodology of the Literature Review}

The literature that was reviewed was found in PubMed, EMBASE, and the Web of Science. The following keywords were used to search the databases: 'ginseng', 'red ginseng', 'Korean ginseng', 'American ginseng', and 'Indian ginseng'. Phrases were also used to search the related literature, such as "ginseng in respiratory disease", "role of ginseng in COPD", "ginseng in acute respiratory infections", and "role of ginseng in respiratory tract infection". The PubMed database revealed an increasing trend in the number of published articles, particularly since 2000, as shown in Figure 2. Randomized controlled trials (RCTs) examining the role of ginseng vs placeboes in treating respiratory viral and bacterial infections were reviewed in this article. Relevant animal studies were also covered in this review. 


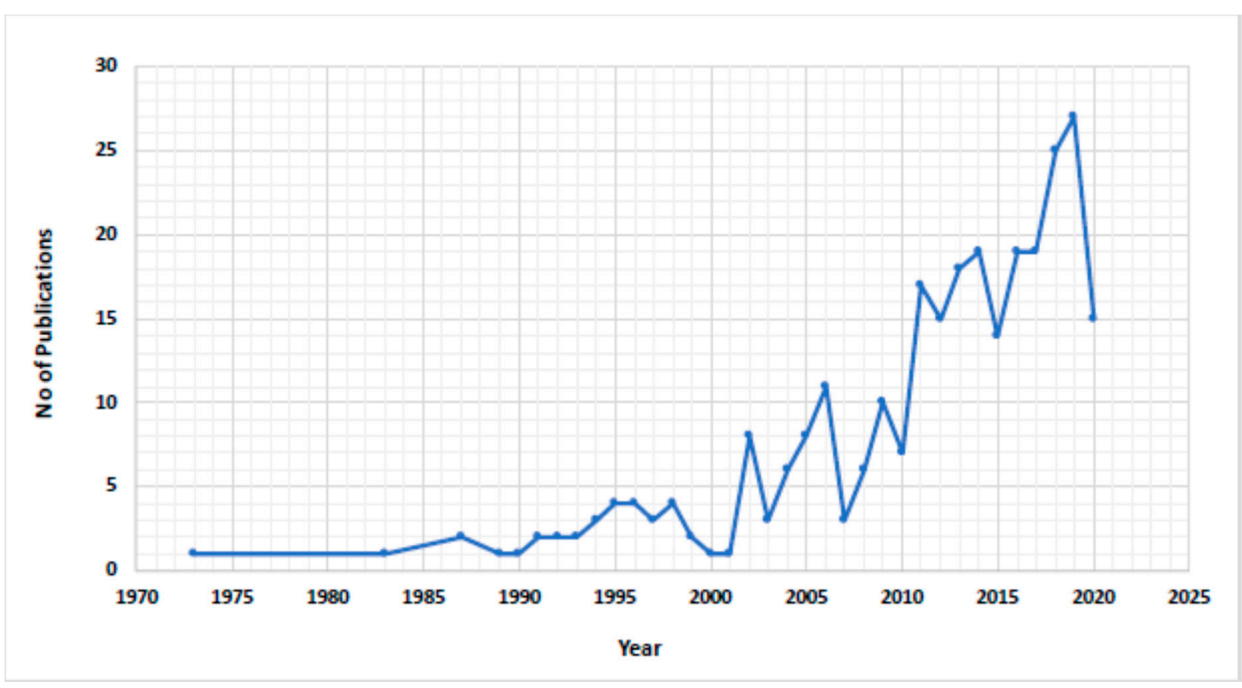

Figure 2. (Search Query: Ginseng in respiratory diseases) The status of publication counts per year Figure 1973.

\section{Ginseng Structural Features}

The primary structural moiety of ginseng saponins is a hydrophobic, four trans-ring rigid steroidal skeleton [27]. Ginsenosides are saponins that are derivatives of triterpene dammarane. Various sugar moieties, such as rhamnose, arabinose, glucose, and xylose, are attached to various carbon positions (C-20, C-6 and C-3) [28]. Each ginsenoside is distinguished by the position of its sugar moiety on the dammarane and triterpene rings. Ginsenosides are generally classified into the following three types: panaxatriol, panaxadiol, and oleanolic [29]. The chemical structures of the three-basic ginseng saponins are shown in Figure 3. The most abundant saponins are protopanaxadiol (PPD; e.g., Ra, Rb, Rc, Rd, Rg3, Rh2) and protopanaxatriol (PPT; e.g., Re, Rf, Rg1, Rg2, Rh1) [30]. More than 40 ginsenosides have been isolated from the root of $P$. ginseng with Rb1, Rb2, Rc, Rd, Rg3, Rh2, Re, Rf, Rg1, $\mathrm{Rg} 2$, and Rh1 being the major isolated ginsenosides. Among the various ginsenosides, Rg1, $\mathrm{Rg} 3, \mathrm{Re}$, and Rd have been the most studied. Most of the studies have focused on the role of ginsenosides, rather than ginseng extract, for treating diseases [6,31-36].

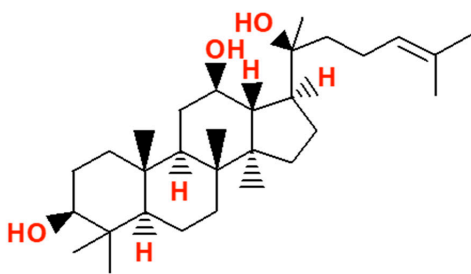

(a) Protopanaxadiol type(PPD)

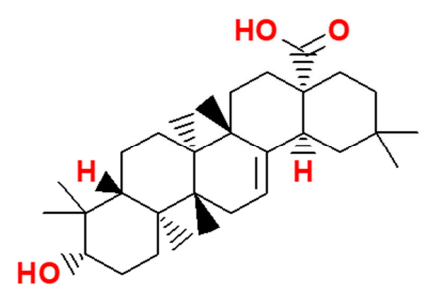

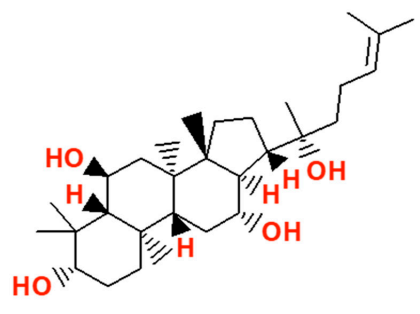

(b) Protopanaxatriop type (PPT)

(c) Oleanolic acid type

Figure 3. Classification of ginsenosides. Most dammarane-type ginsenosides consist of 17 carbons in a four-ring structure with different sugar moieties. (a) protopanaxadiol (PPD), (b) protopanaxatriol (PPT), and (c) Oleanane types [37]. 


\section{Pathogenicity of Microbial Infections}

A family of microbes accountable for diseases is called microbial pathogenicity. A pathogen is a microbe that may produce disease, and the host is an infected organism. A viral or bacterial infection is the leading cause of mortality and morbidity worldwide. This is due to the lack of medicines to combat these infectious diseases. As new contagious diseases emerge, the old ones that were considered to be controlled are re-emerging. Microbes have persisted to adapt, re-adapt, challenge, and survive in the last few decades [38]. Viruses produce respiratory infections by expediting secondary infections, assisting bacterial colonization, adherence, and translocation through the respiratory cells' epithelial barrier [39]. Air pollution is the most significant cause of respiratory tract infections due to urbanization and industrial development. Clinical features do not distinguish the bacterial and viral infections, but they do have different treatment regimes.

The management and treatment of viral and bacterial infections are complex [2]. Viruses promote superinfection via diverse and replete mechanisms, including infecting airways and disregulating innate and acquired immune responses. They promote bacterial growth, adherence, and incursion into sterile sites within the respiratory tract [40]. Rapid molecular diagnostic tests allow us to identify bacterial and viral pathogens [41]. Correct use of cytological criteria, specimen collection, rapid processing, transport, and antibiotic therapy influence the diagnostic yield [42]. A blood culture is recognized as the gold standard for definitive diagnosis of fungal and bacterial infections worldwide. Bacterial infection, atypical pathogens and bacteria from sterile sites are all confirmed by a blood culture [43]. Molecular diagnostic tests have improved our understanding of the role of viruses in pneumonia, suggesting that we may have underestimated viral pneumonia. A patient's age, symptoms, radiographic changes, rapid onset of the disease, and a viral epidemic in the community may help differentiate viral and bacterial infections. No consensus has emerged as to whether to treat patients with community-acquired pneumonia with antibiotics [44]. The pathogenesis of bacterial and viral interactions explains respiratory infections and may help in the advancement of new methods of management, prevention, and treatment of acute respiratory infections [26].

\section{Ginseng's Immunomodulator Effect}

Panax quinquefolius L. (American ginseng), Panax ginseng C. A. Meyer (Korean ginseng), and Panax notoginseng (Chinese ginseng) are the best traditional species of ginseng. They have been shown to possess the potential to improve overall health conditions and mitigate disease symptoms; therefore, these species of ginseng draw special attention [45,46]. $P$. ginseng is plentiful in Korea, China's eastern region, Russia, and Japan. China mainly cultivates P. notoginseng [47,48], while P. quinquefolium is cultivated in Canada and the United States, and has been used by Americans for many years [49]. Ginseng contains Gintonin, which is a non-saponin bioactive component. The chemical properties of gintonin are carbohydrates, lipids, and the ginseng protein complex. It is a glycolipoprotein complex that includes three lipid-derived $G$ protein-coupled receptor ligands lysophosphatidylinositols, lysophosphatidic acids and linoleic acid [50].

Withania somnifera, commonly called as "Indian ginseng," is a popular medicinal herb of India. It contains more than 40 withanolides, 12 alkaloids, and uncommon sitoindosides [51,52]. W. somnifera's main active ingredient is withanaloid. Withanaloid (steroidal lactones) is a class of oxygenated ergostane-type steroids that have a lactone in the side chain and a 2-en-1-one system in the ring. These are mainly withaferin A, withanolides A-Y, withasomniferin- $\mathrm{A}$, withasomidienone, withasomniferols $\mathrm{A}-\mathrm{C}$, withanone, and etc. The two main withanolides, withaferin $\mathrm{A}$ and withanolide $\mathrm{D}$, are responsible for the majority of Ashwaganda's pharmacological effects. W. somnifera's main alkaloids are anaferine, anahygrine, isopelletierine, pseudotropine, tropine, hygrine, mesoanaferine, choline, withananine, hentriacontane, visamine, withasomnine, cuseohygrine, ashwagandhanolide somniferinine, and somniferiene. Sitoindosides VII, sitoindoside VIII, acylsterylglucosides are the saponins of $W$. sominifera $[53,54]$. 
Ginseng exhibits immunomodulatory properties and therapeutic potential against microbial infections. The observed contradiction in ginseng's immunomodulatory properties stems from the extraction method, differences in the origin, laboratory practices, and source of ginseng [55]. Ginseng is comprised of several pharmacologically active ingredients, such as saponins, phytosterols, acidic polysaccharides, amino acids, nitrogenous substances, polyphenolic compounds, polyacetylenes, vitamins, and minerals. These can treat, alleviate, and offer protection against various diseases $[5,37,56]$.

$P$. ginseng has been used to improve vitality, enhance physical performance, and alleviate stress and aging [57]. Korean ginseng comprises about 200 active compounds, including polysaccharides, amino acids, ginsenosides, and peptides [11]. P. quinquefolium is a generally acknowledged herbal remedy and nutritional supplement worldwide [37,58]. Approximately 100 compounds have been isolated from American ginseng. Several differences have been found between American ginseng and Korean ginseng due to their mechanisms of action [59]. However, the primary active components in both are Ginsenosides, Rb1, Rd, Re, Rg1, Rg2, Rg3, Rh1, and Rh2. These components enhance therapeutic activity and stability [60,61]. The pseudoginsenoside F11 in American ginseng and ginsenoside Rf in Korean ginseng and notoginseng differentiate them [59]. Moreover, the ratio of $\mathrm{Rg} 1 / \mathrm{Rb} 1$ also differentiates these ginsengs. American ginseng is represented by a ratio of $\mathrm{Rg} 1 / \mathrm{Rb} 1<0.4$ and Korean ginseng is represented by a ratio of $\operatorname{Rg} 1 / \mathrm{Rb} 1>0.4$ [61]. Sterols and triterpene glycosides belong to a heterogeneous group of saponins and ginsenoside [62]. After an infection challenge, IL-4 and IL-5 cytokine-producing cells are induced by ginseng. Ginseng polysaccharides demonstrate an immune modulator property [63].

Panax ginseng Meyer (P. ginseng; Korean ginseng) has also been shown to possess medicinal properties. It has been used to treat neurological, cardiovascular, immunological, and autoimmune diseases. It has exhibited neurotherapeutic efficacy in treating multiple sclerosis (MS), amyotrophic lateral sclerosis (ALS), Parkinson's, Huntington's, and Alzheimer's disease [64]. Ginsenosides have shown antioxidant effects in cell cultures and animal models $[65,66]$. Direct ROS scavenging effects and ligand-receptor signaling have been suggested as possible mechanisms by which ginsenoside ( $\mathrm{Rb} 1$ ) exerts its antioxidant activity. Most of the ginsenosides have been identified as phytoestrogens. They possess a four trans-ring rigid steroid skeleton with a modified side-chain at C20, which is missing in $17 \beta$-estradiol (E2) $[26,27,67]$. Ginseng has been shown to possess anti-oxidative and anti-inflammatory properties. It enhances cell-mediated immunity associated with healing and tissue repair, and also reduces the symptoms of respiratory tract infections.

\section{Impact of Ginseng on Respiratory Virus Infections}

A virus is a small infectious parasite that cannot replicate by itself. Replication of a virus is only possible in a host, such as the living cells of fungi, bacteria, plants, and animals. Viral diseases include immunodeficiency, autoimmune, cancer, organ-specific infectious diseases, diarrhea, influenza, and the common cold. Viruses are characterized by a simple structure and incredibly small size [64,68-71]. The advancement of vaccines and antiviral therapies has helped us minimize the severity of viral infections and shorten the duration of diseases [72-74]. Ginseng radix has been used as an herbal medicine to treat respiratory diseases. A specific guideline has been developed for its use in clinical practice. A summary of the impact of ginseng on respiratory virus infections has shown in Figure 4. 


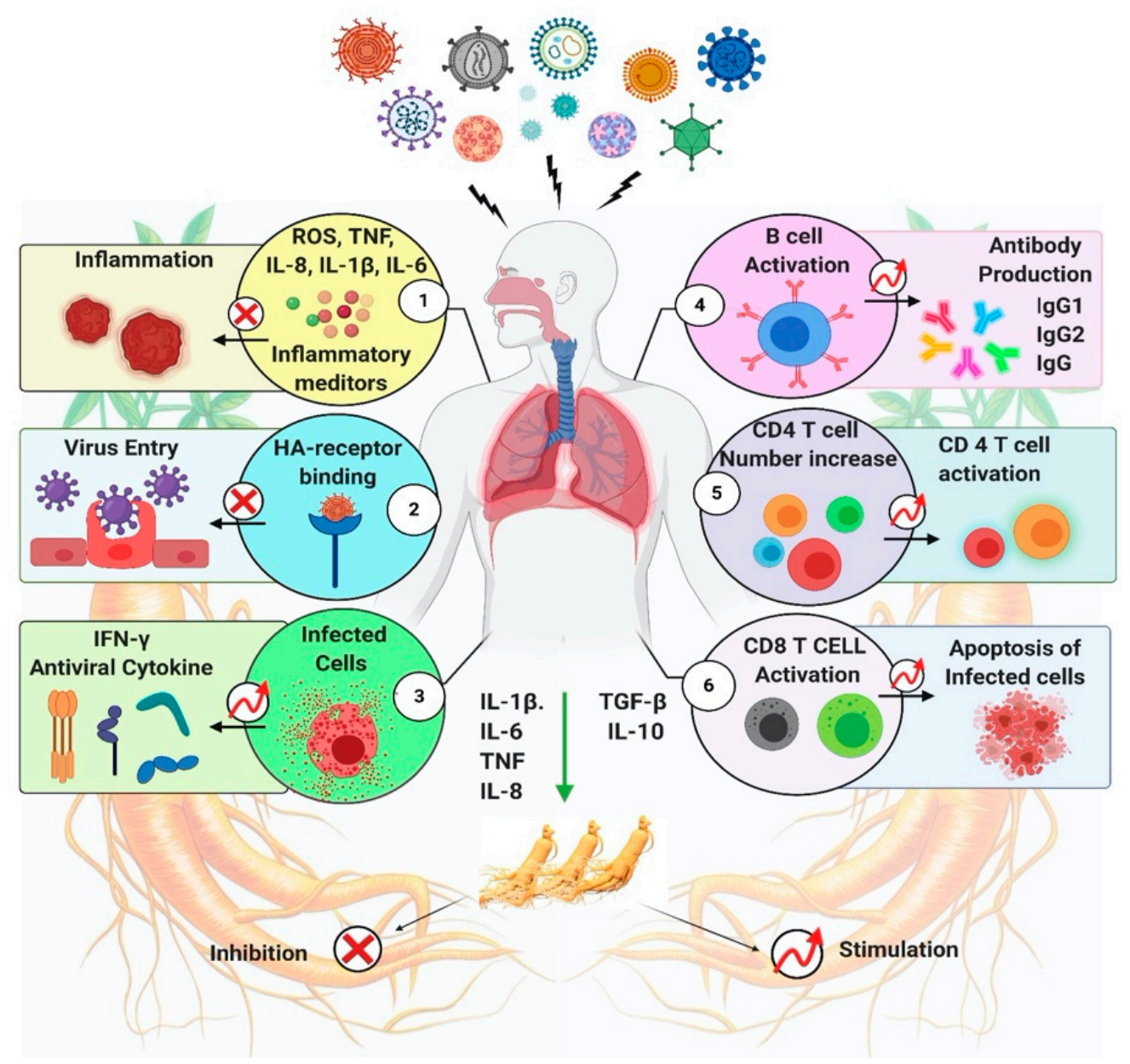

Figure 4. A summary of the impact of ginseng on respiratory virus infections. Ginseng is believed to interrupt through multiple mechanism and shows antiviral effect against respiratory viruses. (1) Ginseng shows anti-inflammatory effects by suppressing inflammatory mediators IL-6, IL-1 $\beta$, IL8, TNF, and ROS. (2) Prevents viral entry into the cells by binding with HA receptor. (3) Stimulates the production of IFN- $\gamma$. Ginseng induces apoptosis of infected cells by stimulating antibody production (4), by activation of CD4+ T cells (5), and CD8 + T cells (6) [37].

\subsection{Influenza Virus}

The influenza virus is a common human respiratory pathogen belonging to the orthomyxoviridae family and is the leading cause of seasonal influenza [75]. This virus is the most common cause of a periodic pandemic and an annual endemic infection. Three types of influenza viruses (A, B, and C) have been found. Human influenza types A and $B$ provoke seasonal infections in winter, while influenza type $C$ induces mild respiratory diseases. Influenza viruses are further classified into subtypes based on the properties of their viral surface proteins hemagglutinin $(\mathrm{H})$ and neuraminidase $(\mathrm{N})$. Lethal strains of the influenza virus have been a cause of deaths worldwide [26,37,75-77]. Several studies have established the potential antiviral activity of red ginseng extracts and their purified components against both in vitro and in vivo influenza A. In vitro, mechanistic studies suggest that ginsenosides, particularly $\mathrm{Rb} 1$, will interact with viral hemagglutinin proteins to prevent attachment of the H1 N1 virus to $\alpha 2-3^{\prime}$ sialic acid receptors on the host cell surface. This results in the minimization of viral entry, thereby decreasing the severity of infection. Fermented Red Ginseng extracts (RGEs), protopanaxadiol [PD], protopanaxatriol [PT], compound $\mathrm{K}$ and $\mathrm{Rh} 2$ exhibited antiviral activity against various influenza subtypes (H1N1, H3N2, H5N1, H7N9) in mouse models [78]. 
Intra-nasal inoculation of mice with fermented ginseng extract and the influenza virus showed improved survival rates. It offered protection against H1N1, H3N2, H5N1, and H7N9 influenza strains and showed a dose-dependent efficacy. Fermented ginseng products exhibited superior anti-viral effects against influenza viruses compared with non-fermented ginseng samples [79]. PT-type ginsenoside Re inhibits virus-induced protein production to protect human umbilical vein endothelial cells from avian H9N2/G1induced cell death. Mucosal adjuvant RGE inhibits influenza virus A/PR8 during viral infections [63]. When inactivated virus and RGE were administered intranasally in mice, researchers observed increased levels of influenza virus-specific antibodies with improved neutralizing activities in blood and mucosal secretions. Specifically, a spike in the IgA antibody was noted in the lungs. This resulted in enhanced secretion of Th1 and Th2-type cytokines in splenocytes in response to the infection challenge. The Th2 type response was more pronounced. The adjuvant effect of RGE was comparable to the effects of conventional adjuvants, such as cholera toxin and aluminum hydroxide.

The role of ginseng in preventing colds has not been clearly determined. Random clinical trials involving ginseng-based proprietary products have provided inconsistent results. A statistically significant reduction in influenza and laboratory-confirmed colds were observed in some of the trials. In contrast, others showed small clinical changes only in upper respiratory tract infections that were not laboratory-confirmed [80].

A double-blind, placebo-controlled four-week study of 227 participants was conducted. Half of the participants were given ginseng at a dosage of $100 \mathrm{mg}$ daily and the other half a placebo. All participants received the influenza vaccine. The finding showed a significant lessening in the frequency of colds and flu in the treated group over the placebo group, and antibody determinations in response to the vaccination were higher in the treated group than in the placebo group [81]. Similarly, North American ginseng has been suggested to help prevent and treat viral respiratory illnesses [82]. The stems and leaves of Panax ginseng showed an adjuvant effect on poultry vaccines [83]. Ginseng stem-leaf saponins (GSLS) combined with selenium have exhibited an adjuvant effect on the live vaccine of Newcastle disease virus, infectious bronchitis virus, and intraocular and intranasal immunization in chickens [84].

\subsection{Respiratory Syncytial Virus}

Respiratory syncytial virus (RSV) belongs to the Paramyxoviridae family. This virus has been shown to cause seasonal pandemics, acute bronchiolitis, and newborn viral deaths [37]. Airborne droplets and close contact can transmit this virus. The symptoms of this viral infection include laryngitis, pharyngitis, rhinitis, and high fever, followed by pneumonia, bronchitis, and often death. Newborns show heavier symptoms, while upper respiratory tract infection is the primary manifestation of the infection in older children and adults [85]. The respiratory syncytial virus mainly affects patients with congenital heart diseases and immunocompromised individuals. To date, no vaccine is available against RSV, despite extensive research efforts [86].

RSV is a negative-sense single-stranded RNA virus. Eleven proteins are coded by its genome, of which the surface proteins $\mathrm{G}$ and $\mathrm{F}$ are essential for RSV binding and fusion, respectively. Of the two proteins, the former is antigenically variable, while the latter is highly conserved. The F protein has a conformational structure which is different before and after fusion. In addition to this, it performs an unpredictable switching between the two structures. The symptoms of bronchiolitis usually peak around four to six days of illness; the peak symptoms cause the airway obstruction due to the host's inflammatory immune response. At present, no curative therapies are available, and the guidelines only cover supportive management of RSV [87]. Viral, host, and environmental factors contribute to disease severity and RSV pathogenesis [88]. Infants infected by RSV bronchiolitis were shown to have a higher level of interleukin 8 (IL-8) than the control group [89]. RSV infection caused an increase in the levels of cytokines (IL-6, IL-8, IL-10), chemokines, and 
tumor necrosis factor-alpha (TNF- $\alpha$ ) in different vitro models and resulted in an imbalance in type 1 and type 2 cytokines [89-92].

In many infectious diseases, ginsenosides and ginseng increase Th cells' immune response by improving the cytokines production of Th1 (IL-2, TNF- $\alpha$, IFN- $\gamma$,) and Th2 (IL-4, IL-10, and IL-13). Ginseng inhibits bacterial infection in mice by increasing serum antibodies IgG1 and IgG2a [93]. The efficacy of ginseng in human clinical trials has been proved via in vivo and in vitro experiments, demonstrating an improved immune response against infections [37]. Ginseng-induced nitric oxide production relaxes the airways and also contracts smooth muscles. Anti-inflammatory and antitumor effects have been exhibited by the Ginsenoside Rh2 (G-Rh2), an active ingredient of ginseng. G-Rh2 has been shown to control allergic airway inflammation by regulating NF- $\mathrm{KB}$ activation and p38 MAPK phosphorylation [94]. Ginsenoside Rg3 suppresses the matrix metalloproteinase (MMP-9) activity and inhibits oxidative stress (superoxide, NO and iNOS) [95]. Ginsenoside RG-II increased pro-inflammatory interferon-gamma (IFN- $\gamma$ ) levels, but lowered the production of IL-4 [96].

\subsection{Rhinoviruses}

Human rhinoviruses (RV) are positive-stranded RNA viruses which cause respiratory tract diseases in children and adults. RV is the causative agent for the common cold in healthy individuals and triggers only mild upper respiratory tract infections. This virus can also cause long-lasting and severe pulmonary infections in people who are immunocompromised and suffering from chronic lung diseases. $[26,97]$. Acute exacerbations of asthma are also caused primarily by rhinoviruses (RVs). An increase in submucosal CD3+ lymphocytes and eosinophils were reported in two studies about rhinovirus-induced airway inflammation in normal and asthmatic subjects. The increase in the number of mucosal CD3+ cells was associated with a corresponding increase in airway responsiveness and correlated positively with cold symptoms [98]. To date, no remedy has been found to treat rhinovirus infection.

Protopanaxatriol (PT)-type ginsenosides (Re, $\mathrm{Rf}$, and Rg2), and protopanaxadiol (PD)type ginsenosides ( $\mathrm{Rb} 1, \mathrm{Rb} 2, \mathrm{Rc}$, and $\mathrm{Rd}$ ) have been studied for their antiviral activity against rhinovirus infection. PT-type ginsenosides were found to protect HeLa cells from human rhinovirus 3 (HRV3)-induced cell death, as determined by sulforhodamine B staining of viable cells and morphological assessment. In contrast, PD-type ginsenosides did not exhibit protective effects and significantly promoted HRV3-induced cell death, indicating a structure-dependent effect for ginsenosides on HRV3. In the case of coxsackievirus, the panaxatriol-type ginsenosides demonstrated limited antiviral behaviours [99].

Korean red ginseng (KRG) showed antiviral activities in a study examining its effects on primary human nasal epithelial cells in human rhinovirus. KRG was used to treat subsequent HRV (human rhinovirus) infection in a study that measured the mRNA and protein levels of the inflammatory cytokine's interleukin IL-8 and IL-6 using real-time polymerase chain reaction and enzyme-linked immunosorbent assay. In primary HNE cells, KRG significantly lessened the HRV-induced upregulation of IL-8, IL-6 mRNA and protein levels. Rhinovirus-induced NF- $\mathrm{KB}$ and MAP kinase activation was also inhibited by KRG treatment. KRG might reduce inflammatory responses to HRV infection, as well as prevent HRV-induced asthma exacerbations [100,101]. Ginsengs were found to affect membrane penetration, inhibit replication inside the cells, and hinder viral attachment.

\subsection{Coronaviruses}

On 11 March 2020, the WHO declared COVID-19 a pandemic. Five pandemics have been globally circulated by a virus since 1918. COVID-19 emerged as the third coronavirus in the past two decades [102-104]. The previous two acute respiratory syndromes, (SARS)$\mathrm{CoV}$ and the Middle East respiratory syndrome (MERS)-CoV, were responsible for severe health issues. Coronavirus spread worldwide from human to human through droplets of infected patients' sneezing and coughing [105]. The common symptoms of COVID-19 are a 
cough, chest tightness, dyspnea, and fatigue, further manifesting into septic shock or sepsis which could cause death [106]. Panax ginseng may be useful here as an immunomodulator and for preventive and supportive therapy [107].

As a treatment for upper respiratory tract diseases, ginseng has been used for thousands of years. Ginseng is capable of binding to the angiotensin-converting enzyme 2 (ACE2) receptor. ACE2 is not the only entry receptor of the coronavirus. COVID-19 might be treated by inhibiting excessive immune cell activation and cytokine production, so ginseng may enhance the immune response, as it has cytokine-modulation activity. Herbal medicines which inhibit 1L-1, IL-6, TNF- $\alpha$, and other pyrogenic cytokines by inhibiting the cytokine storm may also be effective against COVID-19. Several ginsenosides have been recognized as phytoestrogens, binding estrogen receptors [108-110]. These risk factors contribute to a higher concentration of reactive oxygen species and oxidants [111-113]. Antioxidant enzymes stimulate estrogen, which acts as an antioxidant, lessening ROS production $[27,110]$. American ginseng has shown antimicrobial effects against numerous strains of bacteria and also alleviates the detoxifying enzymes, along with the level of reactive oxygen species [114].

Numerous studies have shown the effectiveness of American ginseng extract in treating influenza-infected older adults. It has reduced the incidence of acute respiratory infection in vaccinated and non-vaccinated individuals [114-117]. Ginsenoside Rb1 efficiently lessens ROS production-induced risk factors such as TNF- $\alpha[114,118,119]$. Researchers have suggested that viral infection and immune dysfunctions are due to chronic fatigue syndrome (CFS). It is anticipated that ginsenoside Rg1 reduces the peroxidation product malondialdehyde production and increases nerve cells' antioxidant capacity. It also reduces free radical production in chronic fatigue syndrome, an actual cause of viral infections $[120,121]$. A study was conducted with 100 volunteers to check the efficacy of Korean Red Ginseng's (KRG) against acute respiratory illness. The results suggested that KRG may provide protection from acute respiratory illness or reduce its symptoms [122].

In clinical trials and animal experiments, ginseng has been found to improve protection against pneumococcal pneumonia and influenza. Hence, based on these findings, ginseng may help provide immunity against COVID-19 [123]. W. somnifera is utilized to treat nearly all illnesses that affect human health because of its broad area of activity. Several studies have shown that derivatives of $W$. somnifera can efficiently inhibit various viral infections, including HPV, herpes simplex, parainfuenza-3, HCV, H1N1, bursal disease viruses, and coronaviruses including SARS-CoV and SARS-CoV-2 [124-129]. Since W. somnifera has antiviral, immunomodulatory, anti-inflammatory, and prophylactic properties, the Indian government (Ministry of Ayurveda, Yoga \& Naturopathy, Unani, Siddha, and Homoeopathy), as well as the Council of Scientific and Industrial Research and the Indian Council of Medical Research, have recently approved its use in clinical trials against SARS-CoV-2 [130]. Table 1 shows the effects of ginseng on different respiratory virus infections. The probable role of ginseng for coronavirus is shown in Figure 5 [131]. A fourteen-day clinical trial was recently conducted to study the efficacy of the Shenhuang granule containing Panax ginseng, Rheum palmatum L. stem, Sargentodoxa cuneata, Taraxacum mongolicum, Aconiti lateralis, Radix praeparata, and Whitmania pigra. The trial showed improvement in the condition of severe COVID-patients [106]. Thus, it is advisable to choose a reliable ginseng product as adjuvant therapy for COVID patients. 
Table 1. Effects of ginseng on different respiratory viruses' infections.

\begin{tabular}{|c|c|c|c|c|c|}
\hline $\begin{array}{l}\text { Ginseng Extracts } \\
\text { and Compounds }\end{array}$ & Respiratory Viruses & Study Type & Observations & Conclusions & Reference \\
\hline $\begin{array}{l}\text { seven compounds- } \\
\text { mainly belonging to } \\
\text { P. ginseng }\end{array}$ & Coronavirus & $\begin{array}{c}\text { Glide docking program } \\
\text { was utilized for } \\
\text { molecular docking }\end{array}$ & $\begin{array}{l}\text { Floralginsenoside B, which is } \\
\text { extracted from Panax ginseng, } \\
\text { indicated a docking score of } \\
\text {-8.61 Kcal/mole and showed } \\
\text { high binding affinity by } \\
\text { interacting with active pocket } \\
\text { residues of } 6 \mathrm{M} 0 \mathrm{~J} \text { mainly } \\
\text { through hydrogen bonds with } \\
\text { Gln474, Cys } 480 \text {, Gly } 482 \text {, } \\
\text { Glu465, and Asp } 467 \text { than other } \\
\text { compounds against the } \\
\text { SARS-CoV-2 Spike RBD. }\end{array}$ & $\begin{array}{l}\text { The extracts and } \\
\text { essential oils of Panax } \\
\text { ginseng could be } \\
\text { introduced as } \\
\text { promising COVID-19 } \\
\text { inhibitors. }\end{array}$ & [132] \\
\hline $\begin{array}{l}\text { Withania somnifera } \\
\text { (Indian ginseng) }\end{array}$ & Coronavirus & $\begin{array}{l}\text { Molecular docking and } \\
\text { dynamics studies }\end{array}$ & $\begin{array}{l}\text { Two different protein targets of } \\
\text { SARS-CoV-2, namely NSP15 } \\
\text { endoribonuclease and receptor } \\
\text { binding domain of prefusion } \\
\text { spike protein from SARS-CoV-2, } \\
\text { were targeted. Molecular } \\
\text { docking studies suggested } \\
\text { Withanoside } X \text { and Quercetin } \\
\text { glucoside from } W \text {. somnifera } \\
\text { have favorable interactions at } \\
\text { the binding site of selected } \\
\text { proteins, that is, } 6 \text { W01 and } 6 \mathrm{M} 0 \mathrm{~J} \text {. }\end{array}$ & $\begin{array}{l}\text { Based on proven } \\
\text { therapeutic potential } \\
\text { against n-CoV-2 } \\
\text { proteins, Indian } \\
\text { ginseng could be one } \\
\text { of the alternatives as } \\
\text { an antiviral agent in } \\
\text { the treatment of } \\
\text { COVID-19. }\end{array}$ & [133] \\
\hline $\begin{array}{l}\text { Panax ginseng and } \\
\text { Schizonepeta tenuifolia }\end{array}$ & $\begin{array}{l}\text { SARS-CoV-2 and } \\
\text { Infuenza A viruses. }\end{array}$ & $\begin{array}{l}\text { In-vitro, Cells and cell } \\
\text { culture, plasmid trans- } \\
\text { fection and virus assembly, } \\
\text { Cytotoxicity assays, } \\
\text { Virus infection and drug } \\
\text { inhibition assays }\end{array}$ & $\begin{array}{l}\text { RDS contains broad-spectrum } \\
\text { antiviral activity, blocking the } \\
\text { infection of SARS-CoV, } \\
\text { SARS-CoV-2, and Infuenza } \\
\text { A viruses. }\end{array}$ & $\begin{array}{l}\text { RDS may broadly } \\
\text { inhibit the infection of } \\
\text { respiratory viruses } \\
\text { such as SARS-CoV, } \\
\text { SARS-CoV-2, and } \\
\text { Infuenza A. }\end{array}$ & [134] \\
\hline $\begin{array}{l}\text { Ginseng stem-leaf } \\
\text { saponins (GSLS) } \\
\text { in combination } \\
\text { with selenium }\end{array}$ & $\begin{array}{l}\text { Newcastle disease } \\
\text { virus and infectious } \\
\text { bronchitis virus }\end{array}$ & Female yellow chickens & $\begin{array}{c}\text { In-vitro, Hemagglutination } \\
\text { inhibition test, Immunohisto- } \\
\text { chemical staining for IgG+, } \\
\text { IgA+ and IgM+ cells, sIgA } \\
\text { assay, RT-qPCR, } \\
\text { Transcriptome analysis. }\end{array}$ & $\begin{array}{l}\text { Enhanced antibody } \\
\text { responses in GSLS-Se } \\
\text { group may be attributed } \\
\text { to the immunomo- } \\
\text { dulatory effects of } \\
\text { GSLS-Se on the } \\
\text { immune-related gene } \\
\text { profile expressed in } \\
\text { the immunocompetent } \\
\text { cells of the HGs. }\end{array}$ & {$[84]$} \\
\hline $\begin{array}{c}\text { Ginseng } \\
\text { stem-and-leaf } \\
\text { saponin (GSLS) }\end{array}$ & $\begin{array}{l}\text { Newcastle } \\
\text { disease virus }\end{array}$ & White layer chickens & $\begin{array}{c}\text { Experiment design, } \\
\text { Hemagglutination inhibition } \\
\text { test, Immunohistochemical } \\
\text { staining for IgG+, IgA+ and } \\
\text { IgM+ cells, sIgA assay, RT-qPCR, } \\
\text { Transcriptome analysis. }\end{array}$ & $\begin{array}{l}\text { GSLS could be a useful } \\
\text { oral adjuvant to } \\
\text { improve vaccine } \\
\text { immunization } \\
\text { in chickens. }\end{array}$ & [135] \\
\hline $\begin{array}{l}\text { Extract of Korean } \\
\text { red ginseng }(R G)\end{array}$ & Influenza A virus & $\begin{array}{l}\text { In vitro and In vivo } \\
\text { mice model }\end{array}$ & $\begin{array}{l}\text { Polysaccharide fraction was } \\
\text { most effective in reducing the } \\
\text { accumulation of } \\
\text { (TNF- } \alpha \text { )/(iNOS)-producing } \\
\text { dendritic cells (tip DCs) in the } \\
\text { mouse lungs. }\end{array}$ & $\begin{array}{l}\text { Polysaccharides of RG } \\
\text { have a pronounced } \\
\text { beneficial effect on the } \\
\text { symptoms of } \\
\text { influenza virus } \\
\text { infection. } \\
\end{array}$ & [136] \\
\hline $\begin{array}{l}\text { Extract of Korean } \\
\text { red ginseng }\end{array}$ & $\begin{array}{l}\mathrm{H} 1 \mathrm{~N} 1 \text { and } \mathrm{H} 3 \mathrm{~N} 2 \\
\text { influenza viruses }\end{array}$ & $\begin{array}{l}\text { In vitro, Naive } \\
\text { mice model }\end{array}$ & $\begin{array}{l}\text { Red ginseng extract showed } \\
\text { significantly enhanced } \\
\text { protection, lower levels of lung } \\
\text { viral titers and interleukin-6, but } \\
\text { higher levels of interferon- } \gamma \\
\text { compared with control mice } \\
\text { having virus infections without } \\
\text { red ginseng extract. }\end{array}$ & $\begin{array}{l}\text { Intake of ginseng } \\
\text { extract will have } \\
\text { beneficial effects on } \\
\text { preventing lethal } \\
\text { infection with } \\
\text { newly emerging } \\
\text { influenza viruses. }\end{array}$ & [137] \\
\hline $\begin{array}{c}\text { Panax ginseng } \\
\text { polysaccharide (PGP) }\end{array}$ & $\begin{array}{c}\text { H1N1 (A/PR/8/34) } \\
\text { and H3N2 } \\
\text { (A/Philippines/82) } \\
\text { influenza viruses }\end{array}$ & In vitro, mice study & $\begin{array}{l}\text { PGP solution showed } \\
\text { moderately enhanced survival } \\
\text { rates and lower levels of lung } \\
\text { viral titers and the inflammatory } \\
\text { cytokine (IL-6). }\end{array}$ & $\begin{array}{l}\text { This study } \\
\text { demonstrated that } \\
\text { PGP can be used } \\
\text { as a remedy } \\
\text { against influenza } \\
\text { viral infection. }\end{array}$ & [138] \\
\hline
\end{tabular}


Table 1. Cont.

\begin{tabular}{|c|c|c|c|c|c|}
\hline $\begin{array}{l}\text { Ginseng Extracts } \\
\text { and Compounds }\end{array}$ & Respiratory Viruses & Study Type & Observations & Conclusions & Reference \\
\hline $\begin{array}{l}\text { Black ginseng (BG) } \\
\text { and red ginseng }(\mathrm{RG})\end{array}$ & $\begin{array}{l}\text { A(H1N1) pdm09 } \\
\text { (A/California/ } \\
\text { 04/2009) virus. }\end{array}$ & In vitro, mice study & $\begin{array}{l}\text { BG displayed a } 100 \% \text { survival } \\
\text { rate against infection, while } \\
\text { mice treated with RG had a } 50 \% \\
\text { survival rate. }\end{array}$ & $\begin{array}{l}\text { BG may be useful as } \\
\text { an alternative antiviral } \\
\text { adjuvant to modulate } \\
\text { immune responses to } \\
\text { influenza A virus. }\end{array}$ & [139] \\
\hline $\begin{array}{c}\text { Fermented } \\
\text { ginseng extracts }\end{array}$ & $\begin{array}{l}\text { Different strains of } \\
\text { influenza viruses, } \\
\text { H1N1, H3N2, H5N1, } \\
\text { and H7N9. }\end{array}$ & $\begin{array}{l}\text { Different genetic } \\
\text { backgrounds of mice } \\
\text { and in the deficient } \\
\text { conditions of key } \\
\text { adaptive immune } \\
\text { components (CD4, } \\
\text { CD8, B cell, MHCII) }\end{array}$ & $\begin{array}{l}\text { In vitro cell culture experiments } \\
\text { showed moderate virus- } \\
\text { neutralizing activity by } \\
\text { fermented ginseng extract, } \\
\text { probably by inhibiting } \\
\text { hemagglutination and } \\
\text { neuraminidase activity. }\end{array}$ & $\begin{array}{l}\text { Fermented ginseng } \\
\text { extracts might provide } \\
\text { a means to treat } \\
\text { influenza disease } \\
\text { regardless of } \\
\text { virus strains. }\end{array}$ & [79] \\
\hline $\begin{array}{l}\text { Red ginseng } \\
\text { extract (RGE) }\end{array}$ & influenza A virus & $\begin{array}{l}\text { In vivo and in vitro, } \\
\text { mice model }\end{array}$ & $\begin{array}{l}\text { RGE was found to improve } \\
\text { survival of human lung } \\
\text { epithelial cells upon influenza } \\
\text { virus infection. Also, RGE } \\
\text { treatment reduced the } \\
\text { expression of pro-inflammatory } \\
\text { genes (IL-6, IL-8). }\end{array}$ & $\begin{array}{l}\text { RGE might have the } \\
\text { potential beneficial } \\
\text { effects on preventing } \\
\text { influenza A virus } \\
\text { infections via its } \\
\text { multiple immunomo- } \\
\text { dulatory functions. }\end{array}$ & {$[90]$} \\
\hline $\begin{array}{l}\text { Ginseng extract } \\
\text { and ginsenosides }\end{array}$ & Influenza A virus & $\begin{array}{l}\text { In vivo and in vitro, } \\
\text { mice model }\end{array}$ & $\begin{array}{l}\text { Ginsenosides protected the } \\
\text { animals from lethal } 2009 \\
\text { pandemic H1N1 infection } \\
\text { and lowered viral titers in } \\
\text { animal lungs. }\end{array}$ & $\begin{array}{l}\text { Ginsenosides are } \\
\text { promising candidates } \\
\text { for the development } \\
\text { of antiviral drugs for } \\
\text { influenza viruses. }\end{array}$ & {$[78]$} \\
\hline Ginseng & $\begin{array}{l}\text { Respiratory } \\
\text { syncytial virus }\end{array}$ & $\begin{array}{l}\text { BALB/c mice after } \\
\text { RSV infection }\end{array}$ & $\begin{array}{l}\text { Ginseng-treated mice that were } \\
\text { non-immunized or previously } \\
\text { immunized with FI-RSV } \\
\text { showed improved protection } \\
\text { against RSV challenge } \\
\text { compared with control mice } \\
\text { without ginseng treatment. }\end{array}$ & $\begin{array}{l}\text { Ginseng can modulate } \\
\text { host immune } \\
\text { responses to FI-RSV } \\
\text { immunization and } \\
\text { RSV infection, resulting } \\
\text { in protective effects } \\
\text { against pulmonary } \\
\text { inflammatory disease. }\end{array}$ & {$[140]$} \\
\hline $\begin{array}{l}\text { Panax Korean } \\
\text { red ginseng } \\
\text { extract (KRGE) }\end{array}$ & $\begin{array}{l}\text { Respiratory } \\
\text { syncytial virus }\end{array}$ & In vitro and in vivo & $\begin{array}{l}\text { KRGE improved the survival } \\
\text { of human lung epithelial cells } \\
\text { against RSV infection and } \\
\text { inhibited RSV replication. }\end{array}$ & $\begin{array}{l}\text { Results suggested that } \\
\text { KRGE has antiviral } \\
\text { activity against } \\
\text { RSV infection }\end{array}$ & {$[141]$} \\
\hline $\begin{array}{l}\text { Red ginseng } \\
\text { extract (RGE) }\end{array}$ & RSV & $\begin{array}{l}\text { In vitro cell culture and } \\
\text { in vivo mouse models }\end{array}$ & $\begin{array}{l}\text { RGE treatment improved lung } \\
\text { viral clearance and enhanced } \\
\text { the production IFN- } \gamma \text { in } \\
\text { bronchoalveolar lavage cells } \\
\text { upon RSV infection of mice. }\end{array}$ & $\begin{array}{l}\text { Ginseng has protective } \\
\text { effects against RSV } \\
\text { infection through } \\
\text { multiple mechanisms. }\end{array}$ & [23] \\
\hline Seven ginsenosides & Human rhinovirus & $\begin{array}{l}\text { Assays for antiviral } \\
\text { activity and cytotoxicity } \\
\text { were carried out by the } \\
\text { sulforhodamine B } \\
\text { method using the } \\
\text { cytopathic effect (CPE) } \\
\text { reduction assay. }\end{array}$ & $\begin{array}{c}\text { The antiviral assays } \\
\text { demonstrated that, of the seven } \\
\text { ginsenosides, the PT-type } \\
\text { ginsenosides (Re, Rf, and Rg2) } \\
\text { possess significant antiviral } \\
\text { activities against CVB3 and } \\
\mathrm{HRV} 3 \text { at a concentration of } \\
100 \mu \mathrm{g} / \mathrm{mL} \text {. Only ginsenoside } \\
\mathrm{Rg} 2 \text { showed significant } \\
\text { anti-EV71 activity with no } \\
\text { cytotoxicity to cells at } \\
100 \mu \mathrm{g} / \mathrm{mL}\end{array}$ & $\begin{array}{l}\text { Ginsenosides Re, Rf, } \\
\text { and Rg2 have the } \\
\text { potential to be } \\
\text { effective in the } \\
\text { treatment of } \\
\text { CVB3, EV71, and } \\
\text { HRV3 infection. }\end{array}$ & {$[142]$} \\
\hline $\begin{array}{l}\text { Withania somnifera } \\
\text { (Indian ginseng) }\end{array}$ & H1N1 Influenza virus & In silico study & $\begin{array}{l}\text { High binding affinity of the WA } \\
\text { toward NA and revealed several } \\
\text { interesting molecular } \\
\text { interactions with the residues } \\
\text { which are catalytically } \\
\text { important during molecular } \\
\text { dynamic simulations. }\end{array}$ & $\begin{array}{l}\text { Several interesting } \\
\text { molecular interactions } \\
\text { with the residues } \\
\text { which are cataly- } \\
\text { tically important } \\
\text { during molecular } \\
\text { dynamic simulations. }\end{array}$ & [143] \\
\hline
\end{tabular}

Abbreviations: HG: Harderian gland; RDS: Respiratory Detox Shot; GSLS: ginseng stem-and-leaf saponins; TNF- $\alpha$ : Tumor Necrosis Factor-alpha; iNOS: inducible nitric oxide synthase; PGP: Panax ginseng polysaccharide; FI-RSV: Formalin-inactivated respiratory syncytial virus; IFN- $\gamma$ : Interferon-Gamma; BALB: Bagg Albino (inbred research mouse strain): IgA + cells, Immunoglobulin A-secreting cells; sIgA: Secretory Immunoglobulin A; NA: Neuraminidase; AI: Avian Influenza; CPE; cell viability and cytopathogenic effect; HRV3: Human rhinovirus 3. 


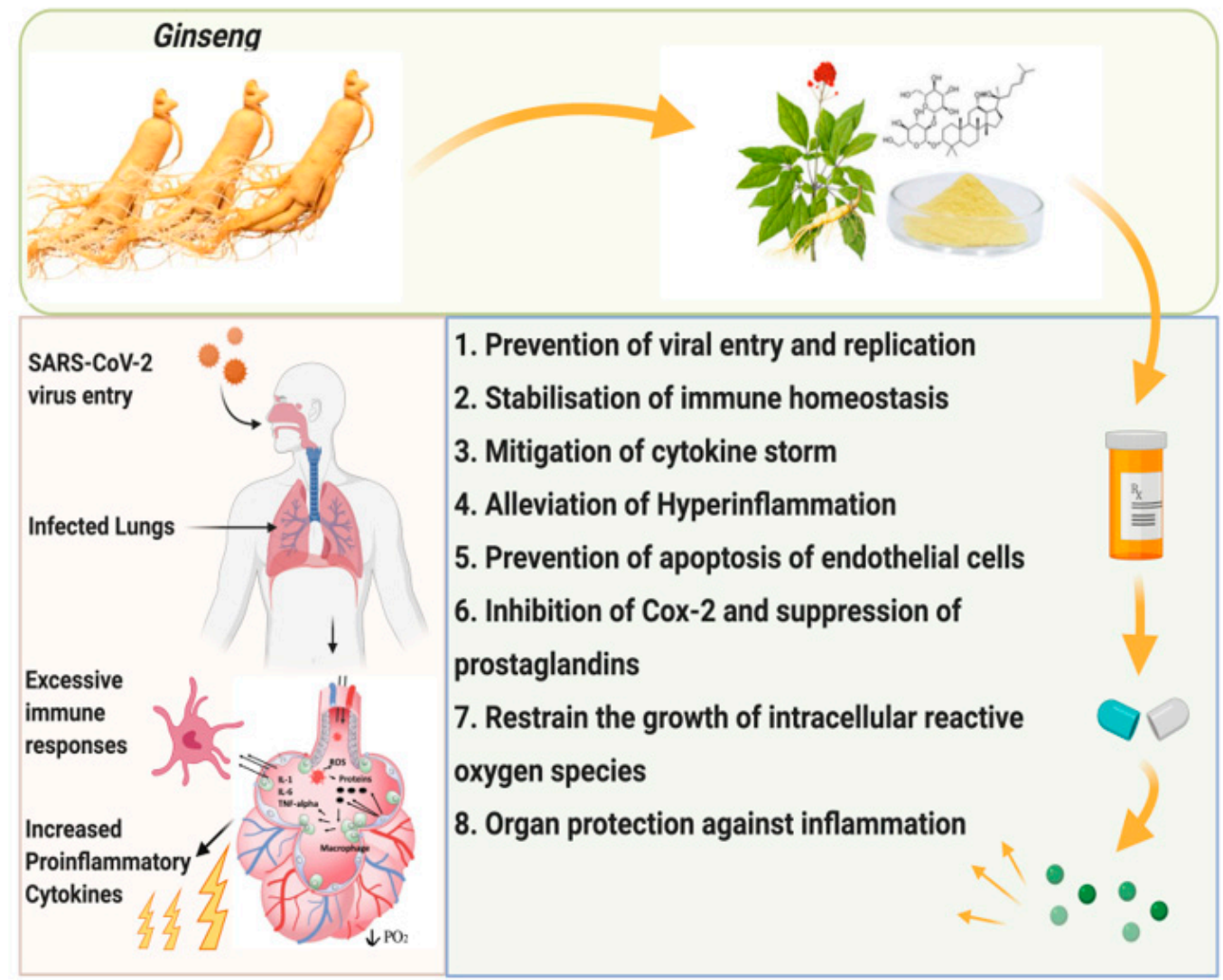

Figure 5. Probable role of Ginseng for coronavirus.

\section{Anti-Bacterial Activity of Ginseng}

Microbial infections have various causes, and the resulting diseases require different antibiotics as treatment. However, the improper use of antibiotics is the cause of resistance and toxic side effects, as well as the emergence of multidrug-resistant bacteria, which is now a global health emergency [144]. In the absence of newer antibiotics, natural products are being promoted to address this issue. Ginseng has been reported to inhibit bacterial pathways, thereby killing bacteria indirectly. It has also been shown to protect the host from bacterial invasion $[145,146]$.

Ginseng exhibits a shielding effect against the inflammation induced by a pathogen. Ginseng exerts this effect via several mechanisms, including anti-quorum sensing, inhibition of pathogen-induced hemagglutination, DNA mutagenesis, and immune-modulatory functions. An impression of ginseng's antibacterial activity is shown in Figure 6. Ginseng and its derived components' anti-bacterial effects are represented in Table 2. 
Table 2. Effects of ginseng on bacterial infections of the respiratory tract.

\begin{tabular}{|c|c|c|c|c|c|}
\hline $\begin{array}{l}\text { Ginseng Extracts } \\
\text { and Compounds }\end{array}$ & Microbe & Study Type & Observations & Conclusions & Reference \\
\hline $\begin{array}{c}\text { Withaferin A } \\
\text { (WA), a withanolide } \\
\text { purified from } \\
\text { Withania somnifera }\end{array}$ & H. pylori & In vitro study & $\begin{array}{l}\text { WA inhibits } H \text {. pylori-induced } \\
\text { IL-8 production in gastric } \\
\text { epithelial cells. }\end{array}$ & $\begin{array}{l}\text { WA does not influence } \\
\text { H. pylori-induced ROS } \\
\text { production or any } \\
\text { associated signaling. }\end{array}$ & [147] \\
\hline $\begin{array}{l}\text { Withania somnifera } \\
\text { (Indian ginseng), } \\
\text { Both aqueous as well } \\
\text { as alcoholic extracts } \\
\text { of the plant (root as } \\
\text { well as leaves) }\end{array}$ & Pathogenic bacteria & In vitro study & $\begin{array}{l}\text { Inhibitory activity against } \\
\text { a spectrum of bacteria. }\end{array}$ & $\begin{array}{c}\text { Increased survival rate } \\
\text { as well as decreased } \\
\text { bacterial load. }\end{array}$ & [148] \\
\hline $\begin{array}{l}\text { Withania somnifera } \\
\text { (Indian ginseng) } \\
\text { extracts }\end{array}$ & $\begin{array}{l}\text { Salmonella typhimurium } \\
\text { and Escherichia coli. }\end{array}$ & In vitro study & $\begin{array}{l}\text { Methanol and hexane extracts } \\
\text { of both leaves and roots were } \\
\text { found to have potent } \\
\text { antibacterial activity. }\end{array}$ & $\begin{array}{l}\text { A synergistic increase in } \\
\text { the antibacterial effect of } \\
\text { Tibrim was noticed } \\
\text { when MIC of Tibrim was } \\
\text { supplemented with } \\
\text { these extracts. }\end{array}$ & [149] \\
\hline $\begin{array}{l}\text { Extracts of } \\
\text { Withania somnifera } \\
\text { (Indian ginseng) }\end{array}$ & $\begin{array}{l}\text { Staphylococcus aureus, } \\
\text { Escherichia coli, } \\
\text { Pseudomonas } \\
\text { aeruginosa and } \\
\text { Bacillus subtilis }\end{array}$ & In vitro study & $\begin{array}{l}\text { Polar solvents had higher } \\
\text { antibacterial property in } \\
\text { comparison with the nonpolar } \\
\text { solvents; higher MIC values } \\
\text { were obtained for both } \\
\text { gram-positive bacteria } \\
\text { S. aureus, B. subtilis and } \\
\text { gram-negative bacteria, } \\
\text { E. coli and P. aeruginosa, } \\
\text { with polar extract. }\end{array}$ & $\begin{array}{l}\text { Antimicrobial activity of } \\
\text { crude extract of } W \text {. } \\
\text { somnifera was shown to } \\
\text { validate the use of } \\
\text { traditional medicinal } \\
\text { herbal medicine and } \\
\text { results of this study tend } \\
\text { to give credence to the } \\
\text { common use of } W \text {. } \\
\text { somnifera plant. }\end{array}$ & [150] \\
\hline $\begin{array}{c}\text { P. ginseng } \\
\text { polysaccharides }\end{array}$ & H. pylori & $\begin{array}{l}\text { hemagglutination and } \\
\text { enzyme-linked } \\
\text { glycosorbent assays }\end{array}$ & $\begin{array}{l}\text { Acidic carbohydrates may play } \\
\text { an important role in the } \\
\text { inhibitory activity on } H \text {. pylori } \\
\text { adhesion to host cells. }\end{array}$ & $\begin{array}{l}\text { Bacterial binding was } \\
\text { inhibited more } \\
\text { effectively by } P \text {. ginseng } \\
\text { polysaccharides }\end{array}$ & [151] \\
\hline $\begin{array}{c}\text { Fermented } \\
\text { ginseng extracts }\end{array}$ & H. pylori & $\begin{array}{l}\text { Formation of clear } \\
\text { zones, measurement of } \\
\text { urease activity and cell } \\
\text { adhesion activity } \\
\text { in vitro. }\end{array}$ & $\begin{array}{l}\text { Anti-H. pylori activity, } \\
\text { including anti-bacterial, } \\
\text { anti-adhesion, and urease } \\
\text { inhibition effects. }\end{array}$ & $\begin{array}{l}\text { Fermented ginseng } \\
\text { extract containing } \\
\text { L.plantarum MG } 208 \\
\text { could prove to be useful } \\
\text { as a functional diet for } \\
\text { the protection of the } \\
\text { gastric environment } \\
\text { against } H \text {. pylori. }\end{array}$ & [152] \\
\hline $\begin{array}{l}\text { Red ginseng } \\
\text { extracts (RGE) }\end{array}$ & H. pylori & $\begin{array}{c}\text { Analysis of cell } \\
\text { viability (trypan blue } \\
\text { dye exclusion assay, } \\
\text { DNA fragmentation } \\
\text { assay (comet assay) } \\
\text { Measurement of } \\
\text { cytokine level, cell } \\
\text { signaling (in vitro) }\end{array}$ & $\begin{array}{l}\text { RGE decreased H. } \\
\text { pylori-stimulated IL-8 gene } \\
\text { expression, which resulted } \\
\text { from the transcriptional } \\
\text { regression of NF- } \kappa \text { B. }\end{array}$ & $\begin{array}{l}\text { RGE showed significant } \\
\text { gastroprotective effects } \\
\text { against } H \text {. pylori- } \\
\text { associated gastric } \\
\text { mucosal cell damage, } \\
\text { suggesting that red } \\
\text { ginseng could be } \\
\text { used as a medicinal } \\
\text { phytonutrient against } \\
\text { H. pylori infection. }\end{array}$ & [153] \\
\hline $\begin{array}{l}\text { White ginseng } \\
\text { extract (WGE) }\end{array}$ & H. pylori & Disc diffusion assay & $\begin{array}{l}\text { The zone of inhibition due to } \\
\text { WGE increased significantly } \\
\text { with increasing dosage. WGE } \\
\text { exhibited an inhibitory effect } \\
\text { on cell growth at } 2.0 \mathrm{mg} / \mathrm{mL} \\
\text { for all tumor cell lines. }\end{array}$ & $\begin{array}{c}\text { The potential of WGE to } \\
\text { be used as a health- } \\
\text { promoting substance. }\end{array}$ & [154] \\
\hline $\begin{array}{l}\text { Ginseng } \\
\text { aqueous extract }\end{array}$ & $\begin{array}{l}\text { Pseudomonas } \\
\text { aeruginosa }\end{array}$ & $\begin{array}{l}\text { P. aeruginosa biofilms } \\
\text { were further } \\
\text { investigated in vitro } \\
\text { and in vivo. }\end{array}$ & $\begin{array}{l}\text { Oral administration of ginseng } \\
\text { extracts in mice promoted } \\
\text { phagocytosis of P. aeruginosa } \\
\text { PAO1 by airway phagocytes } \\
\text { but did not affect phagocytosis } \\
\text { of a PAO1-film mutant. }\end{array}$ & $\begin{array}{l}\text { Ginseng treatment may } \\
\text { help to eradicate the } \\
\text { biofilm-associated } \\
\text { chronic infections } \\
\text { caused by } P \text {. aeruginosa. }\end{array}$ & [155] \\
\hline $\begin{array}{l}\text { Saline extract } \\
\text { of ginseng }\end{array}$ & $\begin{array}{l}\text { Pseudomonas } \\
\text { aeruginosa }\end{array}$ & $\begin{array}{l}\text { Cytokine modulating } \\
\text { effect in a mouse } \\
\text { model of } P \text {. aeruginosa } \\
\text { lung infection. }\end{array}$ & $\begin{array}{l}\text { Th1-like immune response in } \\
\text { the mice with } P \text {. aeruginosa } \\
\text { lung infection after } 7 \text { days } \\
\text { of ginseng treatment. }\end{array}$ & $\begin{array}{l}\text { Th1 response might } \\
\text { benefit the host with } \\
\text { P. aeruginosa lung infection } \\
\text { and ginseng treatment } \\
\text { might be a promising } \\
\text { alternative measure for } \\
\text { the treatment of chronic } \\
\text { P. aeruginosa lung } \\
\text { infection in CF patients. }\end{array}$ & [156] \\
\hline
\end{tabular}


Table 2. Cont.

\begin{tabular}{|c|c|c|c|c|c|}
\hline $\begin{array}{l}\text { Ginseng Extracts } \\
\text { and Compounds }\end{array}$ & Microbe & Study Type & Observations & Conclusions & Reference \\
\hline $\begin{array}{l}\text { Polysaccharide } \\
\text { (PS) isolated from } \\
\text { Panax ginseng }\end{array}$ & Staphylococcus aureus & $\begin{array}{l}\text { In vitro assays for the } \\
\text { activity measurement } \\
\text { of PS, NO production } \\
\text { test with Greiss reagent, } \\
\text { in vivo anti-septicemic } \\
\text { activity was assessed by } \\
\text { using C57BL/6J mice. }\end{array}$ & $\begin{array}{l}\text { Polysaccharide showed } \\
\text { anti-septic effects, Ginsan } \\
\text { enhanced pro-inflammatory } \\
\text { abilities (NO, pro-inflammatory } \\
\text { cytokine production, } \\
\text { phagocytic activity of } \\
\text { macrophages). Ginsan } \\
\text { modulated TLR pathway. }\end{array}$ & $\begin{array}{l}\text { PS from Panax ginseng } \\
\text { possess a potent } \\
\text { anti-septicemic activity } \\
\text { by stimulating } \\
\text { macrophage and } \\
\text { potential as an } \\
\text { immunomodulator } \\
\text { against sepsis caused by } \\
\text { Staphylococcus aureus. }\end{array}$ & [157] \\
\hline $\begin{array}{l}\text { Polysaccharide } \\
\text { (PS) isolated from } \\
\text { Panax ginseng }\end{array}$ & Staphylococcus aureus & In vitro study & $\begin{array}{c}\text { Proinflammatory cytokines, } \\
\text { such as TNF-alpha, IL-1beta, } \\
\text { IL-6, IFN-gamma, IL-12, and } \\
\text { IL-18, were markedly } \\
\text { down-regulated in ginsan- } \\
\text { treated mice compared with } \\
\text { those of control-infected mice. }\end{array}$ & $\begin{array}{l}\text { Antiseptic activity of } \\
\text { ginsan can be attributed } \\
\text { to enhanced bacterial } \\
\text { clearance, and reduced } \\
\text { proinflammatory } \\
\text { cytokines via the TLR } \\
\text { signaling pathway. }\end{array}$ & [158] \\
\hline Korean red ginseng & Staphylococcus aureus & $\begin{array}{l}\text { Fluorescent marker } \\
\text { calcein from negatively } \\
\text { charged PC/PG }(1: 1, \\
w / w) \text { liposomes }\end{array}$ & $\begin{array}{c}\text { Ginsenosides may exert } \\
\text { antibacterial activity by } \\
\text { disrupting the cell membrane }\end{array}$ & $\begin{array}{l}\text { Synergistic or additive } \\
\text { effects between the } \\
\text { ginsenosides and } \\
\text { antibiotics tested }\end{array}$ & [159] \\
\hline $\begin{array}{l}\text { Crude saponins } \\
\text { extracted from the } \\
\text { Panax quinquefolius }\end{array}$ & $\begin{array}{c}\text { Fusobacterium } \\
\text { nucleatum, Clostridium } \\
\text { perfringens, and } \\
\text { Porphyromonas gingivalis }\end{array}$ & $\begin{array}{l}\text { Determination of } \\
\text { MIC, cell integrity }\end{array}$ & $\begin{array}{l}\text { HTS, HTS-3, and HTS-4 were } \\
\text { effective at inhibiting the } \\
\text { growth of F. nucleatum, } \\
\text { C. perfringens, and P. gingivalis. }\end{array}$ & $\begin{array}{l}\text { Less polar ginsenoside- } \\
\text { enriched fraction from } \\
\text { heat transformation can } \\
\text { be used as an } \\
\text { antibacterial agent to } \\
\text { control halitosis. }\end{array}$ & [160] \\
\hline $\begin{array}{l}\text { Acidic polysaccharide } \\
\text { from } P \text {. ginseng, PG-F2 }\end{array}$ & P. gingivalis & Determination of MIC & $\begin{array}{l}\text { Anti-adhesive activity and } \\
\text { anti-hemagglutination. }\end{array}$ & $\begin{array}{c}\text { PG-F2 may exert a } \\
\text { selective antiadhesive } \\
\text { effect against pathogenic } \\
\text { bacteria, while having } \\
\text { no effects on beneficial } \\
\text { and commensal bacteria. }\end{array}$ & [161] \\
\hline $\begin{array}{l}\text { A mixture of roasted } \\
\text { coffee and red ginseng }\end{array}$ & $\begin{array}{l}\text { Pseudomonas } \\
\text { aeruginosa and } S . \\
\text { Typhimurium }\end{array}$ & $\begin{array}{l}\text { Classical paper } \\
\text { disc method }\end{array}$ & $\begin{array}{l}\text { DPPH scavenging activity } \\
\text { decreased when red ginseng } \\
\text { extract composed of more than } \\
70 \% \text { of the total extract. }\end{array}$ & $\begin{array}{l}\text { Antibacterial } \\
\text { activity shown. }\end{array}$ & [162] \\
\hline
\end{tabular}

Abbreviations: WA: Withaferin A; MIC: minimum inhibitory concentration; CF: cystic fibrosis; TLR: toll-like receptor; DPPH: 2,2 diphenyl1-picryl-hydrazyl-hydrate; TNF-alpha: Tumor Necrosis Factor Alpha; ROS: reactive oxygen species; NF-Kb: Nuclear Factor kappa; MBC: minimum bactericidal concentration; KRG: Korean red ginseng; RGE: red ginseng extract; NO: nitric oxide; PC: Phosphatidylcholine; PG; Phosphatidyl glycerol; HTS: heat-transformed saponins; HTS-3 \& HTS 4: Ginsenoside enriched fractions.

\subsection{Pseudomonas Aeruginosa}

Pseudomonas is commonly found in soil, water, and the environment. When people come in contact with this contaminated water or soil, they become infected [37,163]. While multiple types of Pseudomonas exist, Pseudomonas aeruginosa causes most of the infections in humans. This type causes infection in the lungs (pneumonia), but it has evolved to circumvent the effects of the antibiotics used to treat it $[26,37,146]$.

Kharazmi et al. studied the effect of P. ginseng in the treatment of Pseudomonas aeruginosa infection in rats. $P$. ginseng aqueous extract was administered by subcutaneous injection at a dose of $25 \mathrm{mg} / \mathrm{kg}$ of body weight per day, along with saline as a control. After two weeks of treatment, the study showed a significant increase in blood polymorphonuclear leukocyte $(\mathrm{PMN})$ chemiluminescence $(p \leq 0.001)$ with a decrease in the level of serum immunoglobulin $\mathrm{G}(\mathrm{IgG})$ against $P$. aeruginosa $(p<0.05)$. The ginseng-treated infected group showed a higher IgG2a level and lower IgG1 level than the control group. In the ginseng-treated group, the macroscopic lung pathology was milder, with a lower percent of PMNs in the cells collected by broncho-alveolar lavage. The variations in IgG1 and IgG2a subclasses imply a possible shift from a Th-2- to a Th-1 response. The findings of this study suggested that the effect of $P$. ginseng could be related to the activation of a Th- 1 type of cellular immunity and down-regulation of humoral immunity [164]. P. ginseng might also be considered an add-on therapy to treat cystic fibrosis, as it can reduce bacterial infections and biofilm formation. 


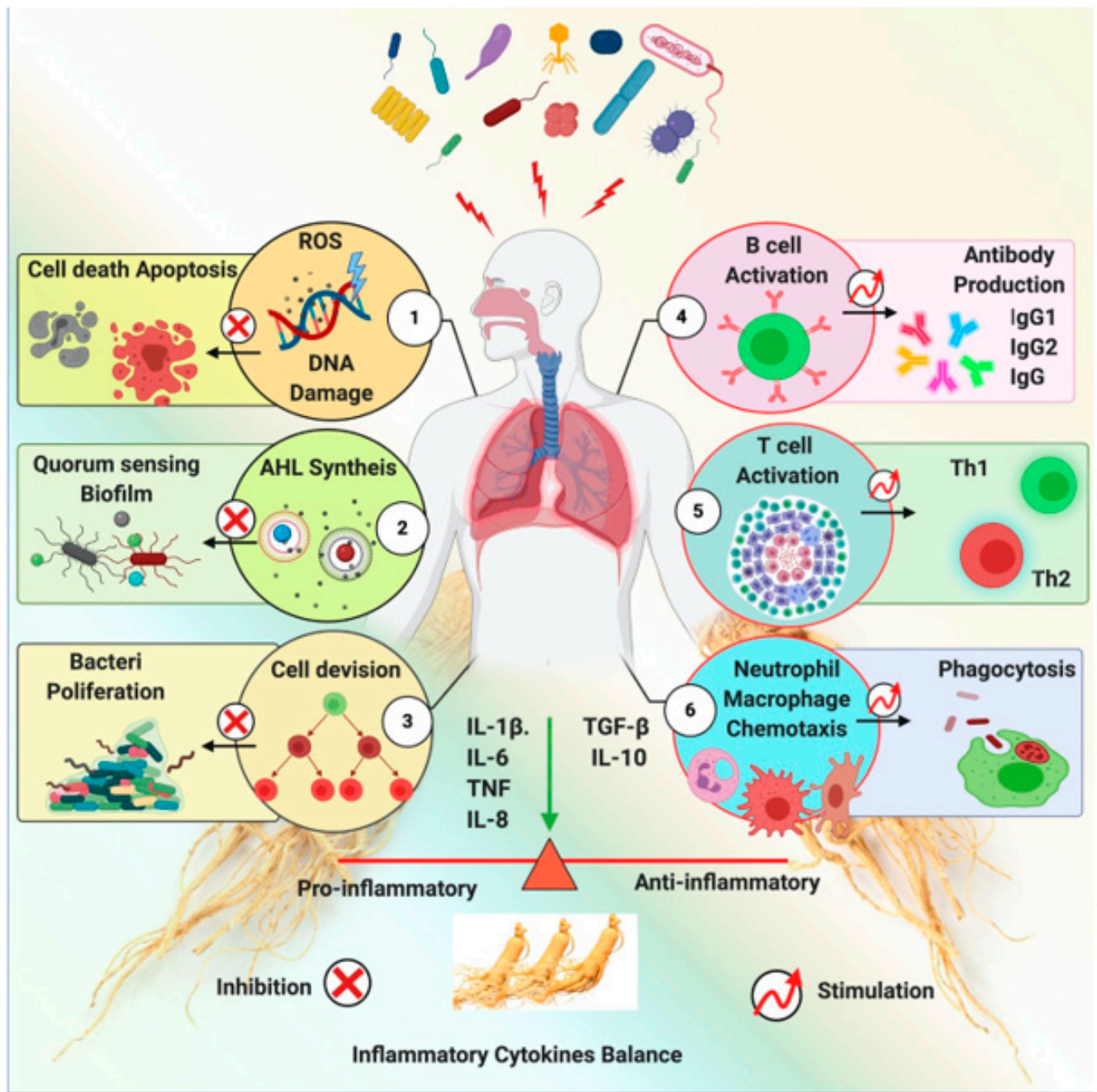

Figure 6. Ginseng and its derived components' anti-bacterial effects via multiple mechanisms. (1) Ginseng inhibits the DNA damage and apoptosis by inhibition of ROS, (2) suppresses AHL-(acyl homoserine lactones) leading to the inhibition of quorum sensing biofilm formation of bacteria, (3) inhibits cell division and bacterial proliferation, (4) stimulates B cell activation and antibody production, (5) activates Th1 and Th2 response, (6) ginseng enhances phagocytosis of Neutrophil and macrophage [37].

Another study was conducted to investigate the antimicrobial activity of the aqueous extract of Panax quinquefolius from North American ginseng (NAGE) root against Pseudomonas aeruginosa. MIC (minimum inhibitory concentrations) of reference and Pseudomonas aeruginosa's clinical isolates were measured by a standard agar dilution method. The extract eradicated six-day-old mature biofilms $(5 \% w / v)$, while luorescence microscopy displayed a reduction of live cells and biofilm complexes compared with non-treated biofilms [165].

Ginseng is a complex mixture of several components, some of which enhance bacterial growth, while others repress it. Thus, the separate components need to be studied. Previous studies via animal models showed that ginseng treatment offered protection from chronic lung infection caused by $P$. aeruginosa. Wu et al. studied ginseng's effect on P. aeruginosa motility and biofilm formation (in vitro and in vivo). Ginseng extract was found to enhance the swimming and twitching motility but reduced the swarming motility. However, an aqueous extract of ginseng in concentrations of $0.5-2.0 \%$ did not inhibit $P$. aeruginosa, but it did significantly limit the formation of P. aeruginosa's biofilm. This study's results suggested that ginseng might alleviate biofilm-associated chronic infections caused by 
P. aeruginosa [155]. Ginseng was reported to have a negative effect on the quorum sensing system of $P$. aeruginosa. This was suggested as a possible mechanism noted in a previous study by which ginseng helped the bacterial clearance from animal lungs in vivo. The ability to enhance and repress bacterial growth could be mutually exclusive [166].

HPLC analysis of ginseng's hot water extract has revealed the presence of six ginsenosides. Therefore, it is essential to isolate and evaluate ginseng's components which contribute to its anti-quorum sensing activity. Ginseng's immunomodulatory functions most probably associate with the activation of Th1 type cellular immune response. These functions deregulate the humoral immune response and lessen the formation of immune complexes [126,137]. Ginseng could play a vital role in combating microbial infections, particularly against $P$. aeruginosa pneumonia. PMNs are a common cause of cystic fibrosis, the leading cause of morbidity and mortality $[167,168]$. Thus, ginseng shows good therapeutic activity against $P$. aeruginosa pneumonia [169].

\subsection{Streptococcus Pneumonia}

Streptococcus pneumoniae (S. pneumoniae) are gram-positive, lancet-shaped, facultativeanaerobic bacteria with over 90 known serotypes. Most of the $S$. pneumoniae produce diseases; a few of the serotypes cause most of the pneumococcal infections. Streptococcus pneumoniae have caused diseases all over the world [146]. The human respiratory tract has commensal Pneumococcus, which is the cause of local infections, as well as many invasive diseases, such as meningitis and sepsis, due to its virulence factors. Korean Red Ginseng (KRG) has been reported to enhance the efficacy of the pneumococcal pep 27 mutant ( $\Delta$ pep27) vaccine [170]. KRG, at a dose of $100 \mathrm{mg} / \mathrm{kg}$, demonstrated higher survival rates in mice than the non-treated controls. Additionally, pre-treated mice showed lower morbidity and bacterial numbers. In vivo, the dosing of $100 \mathrm{mg} / \mathrm{kg}$ of KRG lowered cytokine levels, TNF- $\alpha$ and IL-1 $\beta$, nitric oxide level, and post-infection $48 \mathrm{~h}$ neutrophil infiltration. KRG was shown to defend the host cells from lethal pneumococcal sepsis and also enhanced bacterial clearance. It thereby strengthens cell continuance against pneumococcal infection [171].

Korean Red Ginseng also significantly reduced NF- $\mathrm{BB}$, TLR2, and TLR4 appearance in RAW 264.7 macrophages induced by S. pneumoniae. Korean red ginseng extract's protective effect against pneumococcal infection and sepsis have been investigated. In one study, mice were administered KRG $(25,50,100 \mathrm{mg} / \mathrm{kg})$ for 15 days, then infected with a lethal S. pneumoniae strain. Colonization, survival rate and body weight were calculated. Mice treated with $100 \mathrm{mg} / \mathrm{kg}$ of KRG had significantly higher survival rates and body weights than those of the non-treated controls. A dosage of $100 \mathrm{mg} / \mathrm{kg}$ of KRG protected the host cells from fatal pneumococcal sepsis by inhibiting inflammation and intensifying bacterial clearance, augmenting cell survival against the pneumococcal infection [172].

\section{Ginseng Clinical Trials}

In this section, summaries of human clinical trials from various databases, such as lens.org and clinicaltrial.org, are presented. Only fifteen studies were found for ginseng and respiratory diseases, as noted in Table 3. Ginseng's clinical trials were heterogeneous concerning their variety, species, duration, dose, indications, and participant characteristics. However, in order to illustrate the efficacy and safety of ginseng, future studies need to be stricter and methodologically relevant. No formal inventory has been created showing ginseng in the context of respiratory diseases. Ginseng products are generally used as complementary and alternative medicine in respiratory infections. Most clinical trials have been conducted on $P$. ginseng and included a relatively small number of subjects, ranging from healthy adults to patients with symptoms. More research is needed to explore the uses of ginseng in the context of respiratory diseases. 
Table 3. Human trial findings to evaluate the effectiveness of ginseng against respiratory infections.

\begin{tabular}{|c|c|c|c|c|c|}
\hline Participants & Interventions & Comparisons & Outcomes & Study Design & References \\
\hline $\begin{array}{l}100 \text { participants } \\
\text { Age group } 30-70 \text { years }\end{array}$ & $\begin{array}{c}\text { KRGE } \\
\text { Nine capsules per day } \\
\text { for three months }\end{array}$ & $\begin{array}{l}\text { A Placebo-Controlled } \\
\text { Trial of Korean Red } \\
\text { Ginseng Extract to } \\
\text { Prevent Acute } \\
\text { Respiratory Illness in } \\
\text { Healthy Subjects }\end{array}$ & $\begin{array}{l}\text { Reduced Influenza-such } \\
\text { as illness (ILI) incidence }\end{array}$ & $\begin{array}{l}\text { Interventional } \\
\text { (Clinical Trial) }\end{array}$ & [173] \\
\hline $\begin{array}{c}43 \text { participants } \\
\geq 65 \text { years of age }\end{array}$ & $\begin{array}{l}2 \text { capsules/day } \\
\text { of either COLD-fX } \\
\text { or placebo } \\
\text { (200 mg/capsule) } \\
\text { for } 4 \text { months. }\end{array}$ & COLD-fX or placebo & $\begin{array}{l}\text { Ingestion of COLD-fX by } \\
\text { immunocompetent } \\
\text { seniors during an early } \\
\text { "cold and flu" season } \\
\text { reduced the relative risk } \\
\text { and duration of respiratory } \\
\text { symptoms by } 48 \% \text { and } \\
55 \% \text {, respectively. }\end{array}$ & $\begin{array}{c}\text { A randomized, } \\
\text { double-blind, } \\
\text { placebo-controlled trial. }\end{array}$ & [117] \\
\hline $\begin{array}{l}783 \text { community- } \\
\text { dwelling adults. }\end{array}$ & $\begin{array}{l}\text { Adults were } \\
\text { randomized to receive } \\
\text { placebo, } 400 \mathrm{mg} \text {, or } \\
800 \mathrm{mg} \text { treatment. }\end{array}$ & $\begin{array}{c}\text { CVT-E002 (a } \\
\text { proprietary) } \\
\text { A double-blind, } \\
\text { placebo-controlled trial. }\end{array}$ & $\begin{array}{l}\text { CVT-E002 (a proprietary } \\
\text { extract) can be safely } \\
\text { used by similar groups } \\
\text { and may prevent } \\
\text { URI symptoms, } \\
\text { Jackson-confirmed. }\end{array}$ & $\begin{array}{l}\text { A multicenter, } \\
\text { randomized, } \\
\text { double-blind, } \\
\text { placebo-controlled trial. }\end{array}$ & [174] \\
\hline $\begin{array}{l}747 \text { participants, more } \\
\text { than equal to } 18 \text { years. }\end{array}$ & $\begin{array}{c}\text { North American } \\
\text { (Panax quinquefolius) or } \\
\text { Asian ginseng (Panax } \\
\text { ginseng) root extract or } \\
\text { placebo or no } \\
\text { treatment in healthy } \\
\text { adults were included. }\end{array}$ & $\begin{array}{l}\text { (P. quinquefolius or } \\
\text { P. ginseng) root } \\
\text { extract or placebo }\end{array}$ & $\begin{array}{l}\text { Significantly reduced the } \\
\text { total number of common } \\
\text { colds by } 25 \% \text { compared } \\
\text { with placebo. Tendency } \\
\text { towards lower incidence } \\
\text { of at least one common } \\
\text { cold or other acute } \\
\text { respiratory infection } \\
\text { (ARI) in the ginseng } \\
\text { group compared with } \\
\text { the placebo group. }\end{array}$ & $\begin{array}{l}\text { Randomized controlled } \\
\text { trials or controlled } \\
\text { clinical trials. }\end{array}$ & [175] \\
\hline $\begin{array}{l}\text { Eighty-nine (2000) } \\
\text { and } 109 \text { (2000-2001) } \\
\text { enrolled participants, } \\
\text { average age } 81 \text { and } \\
\text { 83.5, respectively; } \\
74 \% \text { women. }\end{array}$ & $\begin{array}{c}\text { Oral twice-daily } \\
\text { administration of a } \\
\text { proprietary ginseng } \\
\text { extract, CVT-E002, } 200 \\
\text { mg, or placebo. }\end{array}$ & $\begin{array}{l}\text { Proprietary extract of } \\
\text { American ginseng, } \\
\text { CVT-E002, with } \\
\text { placebo in preventing } \\
\text { acute respiratory } \\
\text { illness (ARI) }\end{array}$ & $\begin{array}{l}\text { CVT-E002 was shown to } \\
\text { be safe, well tolerated, } \\
\text { and potentially useful } \\
\text { for preventing ARI due } \\
\text { to influenza and RSV. }\end{array}$ & $\begin{array}{c}\text { Two randomized, } \\
\text { double-blind, } \\
\text { placebo-controlled trials }\end{array}$ & [115] \\
\hline $\begin{array}{l}323 \text { subjects } 18-65 \\
\text { years of age with a } \\
\text { history of at least } 2 \\
\text { colds in the previous } \\
\text { year were recruited } \\
\text { from Edmonton's } \\
\text { general population. }\end{array}$ & $\begin{array}{l}\text { Two capsules per day } \\
\text { of either the North } \\
\text { American ginseng } \\
\text { extract or a placebo } \\
\text { for } 4 \text { months. }\end{array}$ & $\begin{array}{l}\text { North American } \\
\text { ginseng extract } \\
\text { or a placebo. }\end{array}$ & $\begin{array}{l}\text { Moderate dose over } \\
4 \text { months reduced the } \\
\text { mean number of } \\
\text { colds per person. }\end{array}$ & $\begin{array}{c}\text { A randomized, } \\
\text { double-blind, } \\
\text { placebo-controlled }\end{array}$ & [116] \\
\hline $\begin{array}{l}75 \text { subjects, children } \\
3 \text { to } 12 \text { years of age. }\end{array}$ & $\begin{array}{l}\text { Two dosing schedules } \\
\text { of American ginseng } \\
\text { extract during the } \\
\text { winter months }\end{array}$ & $\begin{array}{l}\text { American ginseng } \\
\text { extract or a placebo. }\end{array}$ & $\begin{array}{l}\text { Standard doses of } \\
\text { ginseng were well } \\
\text { tolerated and merit } \\
\text { additional evaluation } \\
\text { concerning pediatric } \\
\text { upper respiratory tract } \\
\text { infection treatment. }\end{array}$ & $\begin{array}{l}\text { A randomized, } \\
\text { double-blind } \\
\text { dose-finding } \\
\text { three-arm trial }\end{array}$ & [176] \\
\hline $\begin{array}{l}14 \text { participants } \\
\text { (57-73 years old) with } \\
\text { moderate to very } \\
\text { severe COPD. }\end{array}$ & $\begin{array}{l}200 \mathrm{mg} \text { twice daily for } \\
\text { four weeks) and then } \\
\text { followed-up for an } \\
\text { additional } 4 \text { weeks for } \\
\text { a total of } 10 \text { weeks. }\end{array}$ & P. ginseng or a placebo & $\begin{array}{l}\text { COPD exacerbations or } \\
\text { adverse events }\end{array}$ & $\begin{array}{l}\text { A randomized, } \\
\text { double-blind, } \\
\text { placebo-controlled } \\
\text { clinical trial }\end{array}$ & [177] \\
\hline 500 children aged 3-11 & $\begin{array}{l}\text { Either COLD-FX or } \\
\text { placebo for } 3 \text { days. }\end{array}$ & COLD-FX or a placebo & No results posted & $\begin{array}{l}\text { A randomized, } \\
\text { double-blind, } \\
\text { placebo-controlled } \\
\text { clinical trial. }\end{array}$ & $\begin{array}{c}\text { ClinicalTrials.gov } \\
\text { identifier (NCT } \\
\text { number): } \\
\text { NCT00965822 }\end{array}$ \\
\hline $\begin{array}{l}200 \text { participants aged } \\
12-75 \text { years. }\end{array}$ & $\begin{array}{c}200 \text { mg twice daily for } \\
4 \text { weeks. } \\
\text { Other Name: } \\
\text { CVT-E002 }\end{array}$ & COLD-FX or a placebo & No results posted & $\begin{array}{l}\text { A randomized, } \\
\text { double-blind, } \\
\text { placebo-controlled } \\
\text { clinical trial. }\end{array}$ & $\begin{array}{c}\text { ClinicalTrials.gov } \\
\text { identifier (NCT } \\
\text { number): } \\
\text { NCT00726401 }\end{array}$ \\
\hline $\begin{array}{l}293 \text { subjects with } \\
\text { early-stage Chronic } \\
\text { Lymphocytic } \\
\text { Leukemia (CLL) }\end{array}$ & $\begin{array}{l}\text { Oral extract for } \\
3 \text { months twice a day }\end{array}$ & COLD-FX or a placebo & $\begin{array}{c}\text { Reduced rates of } \\
\text { moderate-severe } \\
\text { ARI and significantly } \\
\text { less sore throat, } \\
\text { enhanced antibody }\end{array}$ & $\begin{array}{l}\text { A double-blind, } \\
\text { placebo-controlled, } \\
\text { randomized trial. }\end{array}$ & [178] \\
\hline 227 volunteers & $\begin{array}{c}\text { Daily oral capsule } \\
\text { doses of either placebo } \\
\text { (113) or } 100 \text { mg of } \\
\text { standardized ginseng } \\
\text { extract Ginsana G } 115 \\
\text { (114) for } 12 \text { weeks. }\end{array}$ & $\begin{array}{l}\text { Ginsana G } 115(114) \\
\text { Or a placebo }\end{array}$ & $\begin{array}{l}\text { Natural killer (NK) } \\
\text { activity levels two-fold } \\
\text { in the G115 group; can } \\
\text { protect against common } \\
\text { cold and influenza. }\end{array}$ & $\begin{array}{l}\text { Multicenter, two-arm, } \\
\text { randomized, } \\
\text { placebo-controlled, } \\
\text { double-blind }\end{array}$ & [81] \\
\hline
\end{tabular}


Table 3. Cont.

\begin{tabular}{|c|c|c|c|c|c|}
\hline Participants & Interventions & Comparisons & Outcomes & Study Design & References \\
\hline 100 volunteers & $\begin{array}{l}\text { Three times/day, } \\
9 \text { capsules/day, }(3 \\
\text { g/day) for } 12 \text { weeks. }\end{array}$ & $\begin{array}{l}\text { Korean Red Ginseng } \\
\text { (KRG) or a placebo }\end{array}$ & $\begin{array}{l}\text { May be useful in } \\
\text { protecting subjects from } \\
\text { contracting ARI and } \\
\text { may decrease the } \\
\text { duration and scores } \\
\text { of ARI symptoms. }\end{array}$ & $\begin{array}{l}\text { A randomized, } \\
\text { double-blinded, } \\
\text { placebo-controlled }\end{array}$ & [122] \\
\hline $\begin{array}{l}45 \text { healthy applicants } \\
\text { aged 39-65 years }\end{array}$ & $\begin{array}{l}\text { Six capules/day, } \\
500 \text { mg/capsule for } \\
\text { 8 weeks. }\end{array}$ & $\begin{array}{l}\text { GS-3K8 (ultra-filtered } \\
\text { red ginseng extract) } \\
\text { 2. GINst15 } \\
\text { (hydrolyzed ginseng } \\
\text { extract) or a placebo }\end{array}$ & $\begin{array}{l}\text { GS-3K8 and GINST } \\
\text { appear to have a } \\
\text { positive tendency } \\
\text { toward preventing } \\
\text { ARI development } \\
\text { and reducing the } \\
\text { symptom duration. }\end{array}$ & $\begin{array}{c}\text { A randomized, } \\
\text { double-blind, } \\
\text { placebo-controlled, pilot } \\
\text { study at a single center. }\end{array}$ & [179] \\
\hline $\begin{array}{c}328 \text { subjects } \\
\text { Age } \geq 18 \text { Years }\end{array}$ & $\begin{array}{l}\text { Sachet's granules, } \\
\text { Oral route at day } 7\end{array}$ & $\begin{array}{c}\text { Drug: Jing Fang Bai } \\
\text { Du san } \\
\text { Drug: Placebo } \\
\text { Drug: Ying Qiao san }\end{array}$ & $\begin{array}{l}\text { Jing Fang Bai Du San } \\
\text { relieved and effectively } \\
\text { cleared up the } \\
\text { pathogenic cold. Ying } \\
\text { Qiao san effectively } \\
\text { cleared up the } \\
\text { pathogenic heat. }\end{array}$ & $\begin{array}{c}\text { A randomized, } \\
\text { double-blind, } \\
\text { placebo-controlled }\end{array}$ & $\begin{array}{c}\text { ClinicalTrials.gov } \\
\text { identifier (NCT } \\
\text { number): } \\
\text { NCT00887172 }\end{array}$ \\
\hline
\end{tabular}

Abbreviations: ARI: acute respiratory illness; CHM: Chinese herbal medicine; COPD: chronic obstructive pulmonary disease; LCCUs: laboratory-confirmed clinical upper respiratory infections; LCII: laboratory-confirmed influenza illness; NCT: clinical trial number; URTI: upper respiratory tract infection; KRGE: Korean Red Ginseng extract; RSV: respiratory syncytial virus.

\section{Evaluations of Ginseng's Impact on Respiratory Pathogens in Human Clinical Trials}

Ginseng has been used for centuries to cure various diseases. Ginseng's effectiveness has been evaluated in numerous clinical trials exploring treatment of the common cold and flu. Results have shown that ginseng relieves the symptoms and prevents respiratory infections. American ginseng's constituent COLD-fX (CVT-E002) is known as poly-furanosyl-pyranosyl-saccharide. COLD-fX has been isolated from the roots of American ginseng. It is effective and safe against respiratory pathogens, as well as in reducing the viral load of patients who are prone to seasonal influenza. The immunomodulatory constituents of COLD-fX act through toll receptors and influence a rise in cell numbers and functions in innate and adaptive immune systems [180].

A randomized, double-blinded trial investigated the effectiveness of COLD-fX in acute respiratory illness (ARI). Forty-three adults were given a 200 milligram/capsule of COLD-fX or a placebo twice every morning for four months. After one month, the subjects were administered a standard dose of influenza vaccine. The authors did not evaluate the mechanism by which COLD-fX reduced the incidence and duration of ARI in this study. According to the authors, the immune-modulating properties of COLD-fX reported in earlier studies were probably responsible for the observed effect. After the dosing of COLD-fX in mice in vitro, COLD-fX (CVT-E002) was reported to cause a significant increase in lymphocyte proliferation and cytokine production (IL-1, IL-6, TNF- $\alpha$, and nitric oxide) from peritoneal macrophages. The extract's ability to stimulate IL- 2 and IFN- $\gamma$ release could be attributed to its efficacy against respiratory infections. T cell (IFN- $\gamma$, IL-2) and NK cytokines correlate with virus-elicited adaptive immunity. Additionally, COLD-fX reduced the relative risk and duration of respiratory symptoms by $48 \%$ and $55 \%$, respectively, in immunocompromised, aged patients during the influenza season [117]. COLD-fX was also investigated as a seasonal protective drug on 783 patients aged sixty-five years and above. A dosage schedule of 400 or $800 \mathrm{mg}$ /day was given for six months. It was found that COLD-fX was safe and reduced the severity and incidence of upper respiratory tract infections [174].

Seida et al. studied ginseng's efficacy in preventing common colds in healthy adults. A systematic review of randomized controlled trials or controlled clinical trials comparing Asian ginseng (Panax ginseng) and North American (Panax quinquefolius) ginseng root extract to placebo or no treatment groups of healthy adults was carried out. Five trials involving 747 participants were selected for the review. These five trials investigated only North American ginseng and the trials differed in their methodological quality. However, 
in comparison with the placebo groups, ginseng medications reduced common cold symptoms by $25 \%$. The study noted a trend towards a lower incidence of at least one common cold or other respiratory infection in the ginseng-treated group compared with the placebo group. Ginseng lessened the duration of ARIs or colds by 6.2 days as compared with the placebo [175].

Predy et al. studied the efficacy of North American ginseng containing poly-furanosylsaccharides in preventing upper respiratory tract infections. At the beginning of influenza season, a double-blind, randomized, placebo-controlled study was conducted. The trial participants, who had a history of at least two colds in the previous year, were chosen from Edmonton, Alberta. The total number of participants was 323, aged from 18 to 65 years. Participants were given two capsules of North American ginseng extract or placebo daily for four months. A moderate dose of North American ginseng for four months lessened the number of colds per person. The results also showed that participants who had two or more prior cold symptoms had less-severe symptoms than those with no prior symptoms [116].

Mono-preparations of ginseng behave as a placebo, as reported in several clinical trials. The adverse events typically reported by the trials are gastrointestinal disorders, sleepiness, and headache. Isolated cases reported more serious adverse events, but it is difficult to provide evidence of casualty. Ginseng as an add-on therapy has shown severe adverse events and even casualties; however, after reviewing all the cases, it is difficult to conclude that $P$. ginseng could cause the problems. Combination therapy does appear to be more closely associated with adverse events $[15,181]$.

A pilot study of a randomized, controlled trial was conducted to evaluate the efficacy of GINST and GS-3K8 modified ginseng extracts in acute respiratory illness. The study showed that both extracts had a positive impact on ARI treatment, demonstrating reduced symptoms. A more randomized controlled trial is needed to validate these results [180]. A P. ginseng (G115) dose of $100 \mathrm{mg}$ twice daily for 12 weeks improved the pulmonary function test of respiratory endurance in 92 patients with COPD [166]. In two groups of patients [ $(\mathrm{n}=37)(\mathrm{n}=38)]$, the first group was given $875 \mathrm{mg}$ amoxicillin and $125 \mathrm{mg}$ clavulanic acid, while the second group was given an anti-bacterial treatment with $100 \mathrm{mg}$ standardized ginseng extract G115 twice daily for nine days. The bacterial clearance was significantly faster for the ginseng group as compared with the antibiotic-only treatment group. G115 ginseng extract reduced the bacterial counts in patients' bronchial systems. Those patients who have complicated bacterial clearance may receive benefit from ginseng [14]. Additionally, no side effects were reported in the treatment group receiving P. ginseng [15].

Xue et al. evaluated the curative power and safety profile of standard root extract of ginseng (Panax ginseng C.A Meyer). They studied the role of ginseng extract in improving the quality of life and providing symptomatic relief. The research design was a multicentered, randomized, double-blind, placebo-controlled, two-armed parallel clinical trial. The trial involved a total of 168 participants and was conducted at two trial sites in Melbourne, Australia. The participants received 100-mg ginseng capsules or matching placebo twice daily for 24 weeks. The initial result was based on three validated questionnaires of quality of life, and secondary outcomes were based on relief medication usage, lung function testing, exacerbation frequency, and safety. The results of this trial indicated that for chronic respiratory diseases, new remedial development was a possibility. The trial also suggested that ginseng treatment was safe and had remedial value, as it provided symptomatic relief in patients with COPD [7]. In summary, the results of all clinical trials have shown that ginseng and its compounds have protective effects against infectious diseases. As a remedial treatment in respiratory infections, ginseng shows potential for the development of new herbal medicines. More effective clinical trials are still needed to prove the potency and effectiveness of ginseng against respiratory infections.

\section{Conclusions}

Ginseng has been used for centuries as a traditional medicine to cure numerous diseases, but few clinical research studies have been done on its effect on respiratory infections. 
Most clinical trials have focused on studying the probable effects of ginseng on fatigue, memory, menopause symptoms, and mild diabetes symptoms. Between 2002 and 2017, one hundred and thirty-four trials were registered for ginseng, of which $60.4 \%$ were completed and the remaining $23.1 \%$ are actively recruiting participants. Only 15 were registered for lung diseases, demonstrating that ginseng's validity as a remedy for respiratory infections is less well known. However, Panax species phytochemicals are being studied for their natural properties to cure respiratory infections. The stem and leaves have more phytochemicals than the roots, so these plant parts also need to be explored.

Many observed effects have been attributed to $P$. ginseng and its constituent, ginsenosides. It seems that ginsenosides inhibit DNA binding, kinase phosphorylation, ERK1/2, NF- $\mathrm{KB}$ transcription factor, and MAPK induction/translocation as these are functional ligands of glucocorticoid receptors. Ginsenosides reduce proteases such as MMP-9 and pro-inflammatory mediators (ROS, IL-6, IL-8, TNF- $\alpha$ ). Panax ginseng lessens the production of oxidants and enhancing anti-oxidative enzymes to protect against oxidative stress. It can be concluded that respiratory pathogenesis appears to be inhibited by Panax ginseng and ginsenosides; therefore, they could be a promising remedy for the treatment of respiratory diseases.

Herbal medicines and natural plant products are less understood mechanistically, so close attention is needed to understand ginseng's side effects. However, most of the articles suggest that ginseng does not cause adverse effects; it is very well tolerated and efficient in preventing seasonal respiratory infections for all age groups. At the same time, it is necessary to analyze and understand its molecular mechanisms, concentrating on the proteomics procedures, pathway analysis, and applicability of molecular biology's techniques for the identification of the main cellular markers which trigger anti-oxidative and anti-inflammatory effects. It could be helpful to fix those determinants which are accountable for adverse events by frequent use and continued ingestion of standardized ginseng extracts.

Despite the use of ginseng products as alternative and complementary medicine worldwide, a limited number of clinical trials have investigated the efficacy of $P$. ginseng. In these clinical trials, the number of participants was limited but did include healthy subjects and patients with symptoms. Numerous distinct ginsenosides are present in ginseng extracts; thus, more evaluation is required to reveal their full anti-infective potential. More rigorous and methodological research is required for the evaluation of ginseng's effectiveness in respiratory infections.

Author Contributions: Conceptualization and methodology, A.A., D.A. and A.B.M.; writing-original draft preparation, A.A., D.A., A.B.M., S.W. and S.A.; writing-review and editing, A.B.M., S.W. and S.A. All authors have read and agreed to the published version of the manuscript.

Funding: This research received no external funding.

Acknowledgments: The authors would like to express their gratitude to the Deanship of Scientific Research at King Khalid University, Saudi Arabia for providing administrative and technical support.

Conflicts of Interest: The authors confirm that this article content has no conflict of interest.

\section{References}

1. WHO. WHO Technical Report Series 954 Evaluation of Certain Veterinary Drug Residues in Food Seventieth Report of the Joint FAO/WHO Expert Committee on Food Additives Food and Agriculture Organization of the United Nations World Health Organization; WHO: Geneva, Switzerland, 2009; ISBN 9789241209540.

2. Martino, D.; Prescott, S. Epigenetics and prenatal influences on asthma and allergic airways disease. Chest 2011, $139,640-647$. [CrossRef]

3. Brugha, R.; Grigg, J. Urban air pollution and respiratory infections. Paediatr. Respir. Rev. 2014, 15, 194-199. [CrossRef]

4. Cazzola, M.; Page, C.P.; Calzetta, L.; Matera, M.G. Emerging anti-inflammatory strategies for COPD. Eur. Respir. J. 2012, 40, 724-741. [CrossRef] [PubMed]

5. Hyun, S.H.; Kim, S.W.; Seo, H.W.; Youn, S.H.; Kyung, J.S.; Lee, Y.Y.; In, G.; Park, C.K.; Han, C.K. Physiological and pharmacological features of the non-saponin components in Korean Red Ginseng. J. Ginseng Res. 2020, 44, 527-537. [CrossRef] 
6. Ishihara, Y.; Takemoto, T.; Ishida, A.; Yamazaki, T. Protective actions of $17 \beta$-Estradiol and progesterone on oxidative neuronal injury induced by organometallic compounds. Oxid. Med. Cell. Longev. 2015, 2015, 1-16. [CrossRef]

7. Xue, C.C.; Shergis, J.L.; Zhang, A.L.; Worsnop, C.; Fong, H.; Story, D.; Da Costa, C.; Thien, F.C.K. Panax ginseng C.A Meyer root extract for moderate Chronic Obstructive Pulmonary Disease (COPD): Study protocol for a randomised controlled trial. Trials 2011, 12, 1-6. [CrossRef] [PubMed]

8. Bilia, A.R. Science meets regulation. J. Ethnopharmacol. 2014, 158, 487-494. [CrossRef]

9. Blumenthal, M. The ABC Clinical Guide to Herbs; American Botanical Council: Austin, TX, USA, 2003.

10. Jia, L.; Zhao, Y.; Liang, X.-J. Current Evaluation of the Millennium Phytomedicine- Ginseng (II): Collected Chemical Entities, Modern Pharmacology, and Clinical Applications Emanated from Traditional Chinese Medicine. Curr. Med. Chem. 2009, 16, 2924-2942. [CrossRef] [PubMed]

11. Attele, A.S.; Wu, J.A.; Yuan, C.S. Ginseng pharmacology: Multiple constituents and multiple actions. Biochem. Pharmacol. 1999, 58, 1685-1693. [CrossRef]

12. An, X.; Zhang, A.L.; Yang, A.W.; Lin, L.; Wu, D.; Guo, X.; Shergis, J.L.; Thien, F.C.K.; Worsnop, C.J.; Xue, C.C. Oral ginseng formulae for stable chronic obstructive pulmonary disease: A systematic review. Respir. Med. 2011, 105, 165-176. [CrossRef]

13. Gross, D.; Krieger, D.; Efrat, R.; Dayan, M. Ginseng extract G115 ${ }^{\circledR}$ for the treatment of chronic respiratory diseases. Sczeiz. Z. Ganzheits. Med. 1995, 1, 29-33.

14. Scaglione, F.; Weiser, K.; Alessandria, M. Effects of the standardised ginseng extract G115 ${ }^{\circledR}$ in patients with chronic bronchitis: A nonblinded, randomised, comparative pilot study. Clin. Drug Investig. 2001, 21, 41-45. [CrossRef]

15. Coon, J.T.; Ernst, E. Panax ginseng. Drug Saf. 2002, 25, 323-344. [CrossRef] [PubMed]

16. Shibata, S.; Tanaka, O.; Ishii, T.; Fujita, M.; Itokawa, H. Studies on the Constituents of Japanese and Chinese Crude Drugs. XI.* Panaxadiol, A Sapogenin of Ginseng Roots. (2). Chem. Pharm. Bull. 1963, 11, 759-761. [CrossRef]

17. Leung, K.W.; Wong, A.S. Pharmacology of ginsenosides: A literature review. Chin. Med. 2010, 5, 1-7. [CrossRef] [PubMed]

18. Sung, W.S.; Lee, D.G. In Vitro Candidacidal Action of Korean Red Ginseng Saponins against Candida albicans. Biol. Pharm. Bull. 2008, 31, 139-142. [CrossRef]

19. Mallavadhani, U.V.; Mahapatra, A.; Raja, S.S.; Manjula, C. Antifeedant activity of some pentacyclic triterpene acids and their fatty acid ester analogues. J. Agric. Food Chem. 2003, 51, 1952-1955. [CrossRef]

20. Katerere, D.R.; Gray, A.I.; Nash, R.J.; Waigh, R.D. Antimicrobial activity of pentacyclic triterpenes isolated from African Combretaceae. Phytochemistry 2003, 63, 81-88. [CrossRef]

21. Ginseng: Nature's Anti-Inflammatory?-ScienceDaily. Available online: https://www.sciencedaily.com/releases/2009/05/0905 13215410.htm (accessed on 1 December 2020).

22. Lee, D.C.W.; Yang, C.L.H.; Chik, S.C.C.; Li, J.C.B.; Rong, J.H.; Chan, G.C.F.; Lau, A.S.Y. Bioactivity-guided identification and cell signaling technology to delineate the immunomodulatory effects of Panax ginseng on human promonocytic U937 cells. J. Transl. Med. 2009, 7, 34. [CrossRef] [PubMed]

23. Lee, J.S.; Lee, Y.N.; Lee, Y.-T.; Hwang, H.S.; Kim, K.-H.H.; Ko, E.-J.J.; Kim, M.-C.C.; Kang, S.-M.M. Ginseng Protects Against Respiratory Syncytial Virus by Modulating Multiple Immune Cells and Inhibiting Viral Replication. Nutrients 2015, 7, $1021-1036$. [CrossRef]

24. Silvestrini, P.; Beccaria, C.; Pereyra, E.A.L.; Renna, M.S.; Ortega, H.H.; Calvinho, L.F.; Dallard, B.E.; Baravalle, C. Intramammary inoculation of Panax ginseng plays an immunoprotective role in Staphylococcus aureus infection in a murine model. Res. Vet. Sci. 2017, 115, 211-220. [CrossRef] [PubMed]

25. Zhuo, X.; Sun, H.; Wang, S.; Guo, X.; Ding, H.; Yang, Y.; Shan, Y.; Du, A. Ginseng stem-and-leaf saponin (GSLS)-Enhanced protective immune responses induced by Toxoplasma gondii heat shocked protein 70 (HSP70) against toxoplasmosis in mice. J. Parasitol. 2017, 103, 111-117. [CrossRef] [PubMed]

26. Iqbal, H.; Rhee, D. kwon Ginseng alleviates microbial infections of the respiratory tract: A review. J. Ginseng Res. 2020, 44, 194-204. [CrossRef] [PubMed]

27. Lü, J.M.; Jiang, J.; Jamaluddin, M.S.; Liang, Z.; Yao, Q.; Chen, C. Ginsenoside Rb1 blocks ritonavir-induced oxidative stress and eNOS downregulation through activation of estrogen receptor-beta and upregulation of SOD in human endothelial cells. Int. J. Mol. Sci. 2019, 20, 294. [CrossRef]

28. Shin, K.C.; Oh, D.K. Classification of glycosidases that hydrolyze the specific positions and types of sugar moieties in ginsenosides. Crit. Rev. Biotechnol. 2016, 36, 1036-1049. [CrossRef]

29. Chang-Xiao, L.; Pei-Gen, X. Recent advances on ginseng research in China. J. Ethnopharmacol. 1992, 36, 27-38. [CrossRef]

30. Yang, M.S.; Wu, M.Y. Chinese Ginseng. In Nutraceuticals; Elsevier: Amsterdam, The Netherlands, 2016; pp. 693-705, ISBN 9780128021477.

31. Lee, C.H.; Kim, J.H. A review on the medicinal potentials of ginseng and ginsenosides on cardiovascular diseases. J. Ginseng Res. 2014, 38, 161-166. [CrossRef]

32. CHENG, Y.; SHEN, L.; ZHANG, J. Anti-amnestic and anti-aging effects of ginsenoside Rg1 and Rb1 and its mechanism of action. Acta Pharmacol. Sin. 2005, 26, 143-149. [CrossRef] [PubMed]

33. Zhou, W.; Chai, H.; Lin, P.H.; Lumsden, A.B.; Yao, Q.; Chen, C. Molecular mechanisms and clinical applications of ginseng root for cardiovascular disease. Med. Sci. Monit. 2004, 10, RA187-RA192. 
34. Lim, K.H.; Lim, D.J.; Kim, J.H. Ginsenoside-Re ameliorates ischemia and reperfusion injury in the heart: A hemodynamics approach. J. Ginseng Res. 2013, 37, 283-292. [CrossRef] [PubMed]

35. Buettner, C.; Yeh, G.Y.; Phillips, R.S.; Mittleman, M.A.; Kaptchuk, T.J. Systematic review of the of ginseng on cardiovascular risk factors. Ann. Pharmacother. 2006, 40, 83-95. [CrossRef] [PubMed]

36. Gillis, C.N. Panax ginseng pharmacology: A nitric oxide link? Biochem. Pharmacol. 1997, 54, 1-8. [CrossRef]

37. Nguyen, N.H.; Nguyen, C.T. Pharmacological effects of ginseng on infectious diseases. Inflammopharmacology 2019, 27, 871-883. [CrossRef]

38. Fonkwo, P.N. Pricing infectious disease. EMBO Rep. 2008, 9, S13-S17. [CrossRef]

39. Anderson, B.D.; Gray, G.C. Emerging and reemerging infectious diseases. In Encyclopedia of Microbiology; Nature Publishing Group: Berlin, Germany, 2019; pp. 112-122, ISBN 9780128117378.

40. Bakaletz, L.O. Viral-bacterial co-infections in the respiratory tract. Curr. Opin. Microbiol. 2017, 35, 30-35. [CrossRef] [PubMed]

41. Warhurst, G.; Dunn, G.; Chadwick, P.; Blackwood, B.; McAuley, D.; Perkins, G.D.; McMullan, R.; Gates, S.; Bentley, A.; Young, D.; et al. Rapid detection of health-care-associated bloodstream infection in critical care using Multipathogen real-time polymerase chain reaction technology: A diagnostic accuracy study and systematic review. Health Technol. Assess. 2015, 19, 1-141. [CrossRef] [PubMed]

42. Mandell, L.A.; Wunderink, R.G.; Anzueto, A.; Bartlett, J.G.; Campbell, G.D.; Dean, N.C.; Dowell, S.F.; File, T.M.; Musher, D.M.; Niederman, M.S.; et al. Infectious Diseases Society of America/American Thoracic Society Consensus Guidelines on the management of community-acquired pneumonia in adults. Clin. Infect. Dis. 2007, 44, S27-S72. [CrossRef] [PubMed]

43. Bloomfield, M.G.; Balm, M.N.D.; Blackmore, T.K. Molecular testing for viral and bacterial enteric pathogens: Gold standard for viruses, but don't let culture go just yet? Pathology 2015, 47, 227-233. [CrossRef]

44. Ruuskanen, O.; Lahti, E.; Jennings, L.C.; Murdoch, D.R. Viral pneumonia. Lancet 2011, 377, 1264-1275. [CrossRef]

45. Yu, C.; Wang, C.Z.; Zhou, C.J.; Wang, B.; Han, L.; Zhang, C.F.; Wu, X.H.; Yuan, C.S. Adulteration and cultivation region identification of American ginseng using HPLC coupled with multivariate analysis. J. Pharm. Biomed. Anal. 2014, 99, 8-15. [CrossRef] [PubMed]

46. Yang, L.; Yu, Q.-T.; Ge, Y.-Z.; Zhang, W.-S.; Fan, Y.; Ma, C.-W.; Liu, Q.; Qi, L.-W. Distinct urine metabolome after Asian ginseng and American ginseng intervention based on GC-MS metabolomics approach. Sci. Rep. 2016, 6, 39045. [CrossRef] [PubMed]

47. Lee, O.R.; Nguyen, N.Q.; Lee, K.H.; Kim, Y.C.; Seo, J. Cytohistological study of the leaf structures of Panax ginseng Meyer and Panax quinquefolius L. J. Ginseng Res. 2017, 41, 463-468. [CrossRef]

48. Pan, Y.; Wang, X.; Sun, G.; Li, F.; Gong, X. Application of RAD sequencing for evaluating the genetic diversity of domesticated Panax notoginseng (Araliaceae). PLoS ONE 2016, 11. [CrossRef] [PubMed]

49. Borchers, A.T.; Keen, C.L.; Stern, J.S.; Gershwin, M.E. Inflammation and Native American medicine: The role of botanicals. Am. J. Clin. Nutr. 2000, 72, 339-347. [CrossRef] [PubMed]

50. Choi, S.-H.; Lee, R.; Nam, S.M.; Kim, D.-G.; Cho, I.-H.; Kim, H.-C.; Cho, Y.; Rhim, H.; Nah, S.-Y. Ginseng gintonin, aging societies, and geriatric brain diseases. Integr. Med. Res. 2021, 10, 100450. [CrossRef] [PubMed]

51. Mirjalili, M.H.; Moyano, E.; Bonfill, M.; Cusido, R.M.; Palazón, J. Steroidal lactones from Withania somnifera, an ancient plant for novel medicine. Molecules 2009, 14, 2373-2393. [CrossRef]

52. Straughn, A.R.; Kakar, S.S. Withaferin A: A potential therapeutic agent against COVID-19 infection. J. Ovarian Res. 2020, 13, 1-5. [CrossRef]

53. Gaurav, N. A Review: Pharmacological and Medicinal Activity of Active Compounds of Withania somnifera. J. Eng. Technol. 2013, 3, 2231.

54. Tiwari, R.; Chakraborty, S.; Saminathan, M.; Dhama, K.; Singh, S.V. Ashwagandha (Withania somnifera): Role in safeguarding health, immunomodulatory effects, combating infections and therapeutic applications: A Review. J. Biol. Sci. 2014, 14, 77-94. [CrossRef]

55. Shergis, J.L.; Di, Y.M.; Zhang, A.L.; Vlahos, R.; Helliwell, R.; Ye, J.M.; Xue, C.C. Therapeutic potential of Panax ginseng and ginsenosides in the treatment of chronic obstructive pulmonary disease. Complement. Med. 2014, 22, 944-953. [CrossRef] [PubMed]

56. Park, J.D.; Rhee, D.K.; Lee, Y.H. Biological activities and chemistry of saponins from Panax ginseng C. A. Meyer. Phytochem. Rev. 2005, 4, 159-175. [CrossRef]

57. Scaglione, F.; Ferrara, F.; Dugnani, S.; Falchi, M.; Santoro, G.; Fraschini, F. Immunomodulatory effects of two extracts of Panax ginseng C.A. Meyer. Drugs Exp. Clin. Res. 1990, 16, 537-542.

58. Cui, L.; Wu, S.Q.; Zhao, C.A.; Yin, C.R. Microbial conversion of major ginsenosides in ginseng total saponins by Platycodon grandiflorum endophytes. J. Ginseng Res. 2016, 40, 366-374. [CrossRef]

59. Choi, K.T. Botanical Characteristics, Pharmacological Effects and Medicinal Components of Korean Panax ginseng C A Meyer; John Wiley \& Sons, Ltd.: Hoboken, NJ, USA, 2008; Volume 29, pp. 1109-1118.

60. Helms, S. Cancer prevention and therapeutics: Panax ginseng. Altern. Med. Rev. 2004, 9, 259-274. [PubMed]

61. Kim, W.Y.; Kim, J.M.; Han, S.B.; Lee, S.K.; Kim, N.D.; Park, M.K.; Kim, C.K.; Park, J.H. Steaming of ginseng at high temperature enhances biological activity. J. Nat. Prod. 2000, 63, 1702-1704. [CrossRef] [PubMed]

62. Song, X.; Hu, S. Adjuvant activities of saponins from traditional Chinese medicinal herbs. Vaccine 2009, 27, 4883-4890. [CrossRef] 
63. Quan, F.S.; Compans, R.W.; Cho, Y.K.; Kang, S.M. Ginseng and Salviae herbs play a role as immune activators and modulate immune responses during influenza virus infection. Vaccine 2007, 25, 272-282. [CrossRef]

64. Lee, J.I.; Park, K.S.; Cho, I.H. Panax ginseng: A candidate herbal medicine for autoimmune disease. J. Ginseng Res. 2019, 43, 342-348. [CrossRef]

65. Kim, C.J.; Ryu, H.Y.; Lee, S.; Lee, H.J.; Chun, Y.S.; Kim, J.K.; Yu, C.Y.; Ghimire, B.K.; Lee, J.G. Neuroprotective effect and antioxidant potency of fermented cultured wild ginseng root extracts of Panax ginseng C.A. meyer in mice. Molecules 2021, 26, 3001. [CrossRef]

66. Saw, C.L.L.; Yang, A.Y.; Cheng, D.C.; Boyanapalli, S.S.S.; Su, Z.Y.; Khor, T.O.; Gao, S.; Wang, J.; Jiang, Z.H.; Kong, A.N.T. Pharmacodynamics of ginsenosides: Antioxidant activities, activation of Nrf2, and potential synergistic effects of combinations. Chem. Res. Toxicol. 2012, 25, 1574-1580. [CrossRef] [PubMed]

67. Lu, J.-M.; Yao, Q.; Chen, C. Ginseng Compounds: An Update on Their Molecular Mechanisms and Medical Applications. Curr. Vasc. Pharmacol. 2009, 7, 293-302. [CrossRef] [PubMed]

68. Martin, A.; Lemon, S.M. Hepatitis A virus: From discovery to vaccines. Hepatology 2006, 43, S164-S172. [CrossRef]

69. Baek, S.H.; Lee, J.G.; Park, S.Y.; Bae, O.N.; Kim, D.H.; Park, J.H. Pectic polysaccharides from Panax ginseng as the antirotavirus principals in ginseng. Biomacromolecules 2010, 11, 2044-2052. [CrossRef]

70. Song, X.; Chen, J.; Sakwiwatkul, K.; Li, R.; Hu, S. Enhancement of immune responses to influenza vaccine (H3N2) by ginsenoside Re. Int. Immunopharmacol. 2010, 10, 351-356. [CrossRef] [PubMed]

71. Munoz, F.M. Respiratory syncytial virus in infants. Curr. Opin. Infect. Dis. 2015, 28, 221-224. [CrossRef] [PubMed]

72. Porter, K. Determinants of survival following HIV-1 seroconversion after the introduction of HAART. Lancet 2003, 362, 1267-1274. [CrossRef]

73. Munos, M.K.; Fischer Walker, C.L.; Black, R.E. The effect of rotavirus vaccine on diarrhoea mortality. Int. J. Epidemiol. 2010, 39, i56-i62. [CrossRef] [PubMed]

74. Nichol, K.L.; Lind, A.; Margolis, K.L.; Murdoch, M.; McFadden, R.; Hauge, M.; Magnan, S.; Drake, M. The Effectiveness of Vaccination against Influenza in Healthy, Working Adults. N. Engl. J. Med. 1995, 333, 889-893. [CrossRef]

75. Neumann, G.; Chen, H.; Gao, G.F.; Shu, Y.; Kawaoka, Y. H5N1 influenza viruses: Outbreaks and biological properties. Cell Res. 2010, 20, 51-61. [CrossRef] [PubMed]

76. Neumann, G.; Noda, T.; Kawaoka, Y. Emergence and pandemic potential of swine-origin H1N1 influenza virus. Nature 2009, 459, 931-939. [CrossRef]

77. Claas, E.C.J.; Osterhaus, A.D.M.E.; Van Beek, R.; De Jong, J.C.; Rimmelzwaan, G.F.; Senne, D.A.; Krauss, S.; Shortridge, K.F.; Webster, R.G. Human influenza A H5N1 virus related to a highly pathogenic avian influenza virus. Lancet 1998, 351, $472-477$. [CrossRef]

78. Dong, W.; Farooqui, A.; Leon, A.J.; Kelvin, D.J. Inhibition of influenza A virus infection by ginsenosides. PLoS ONE 2017, 12, e0171936. [CrossRef]

79. Wang, Y.; Jung, Y.-J.J.; Kim, K.-H.H.; Kwon, Y.; Kim, Y.-J.J.; Zhang, Z.; Kang, H.-S.S.; Wang, B.-Z.Z.; Quan, F.-S.S.; Kang, S.-M.M. Antiviral Activity of Fermented Ginseng Extracts against a Broad Range of Influenza Viruses. Viruses 2018, 10, 471. [CrossRef] [PubMed]

80. Allan, G.M.; Arroll, B. Prevention and treatment of the common cold: Making sense of the evidence. Can. Med. Assoc. J. 2014, 186, 190-199. [CrossRef] [PubMed]

81. Scaglione, F.; Cattaneo, G.; Alessandria, M.; Cogo, R. Efficacy and safety of the standardized ginseng extract G 115 for potentiating vaccination against common cold and/or influenza syndrome. Drugs Exp. Clin. Res. 1996, 22, 65-72. [PubMed]

82. Shahrajabian, M.H.; Sun, W.; Cheng, Q. Traditional Herbal Medicine for the Prevention and Treatment of Cold and Flu in the Autumn of 2020, Overlapped With COVID-19. Nat. Prod. Commun. 2020, 15, 1934578X2095143. [CrossRef]

83. Yuan, L.; Wang, Y.; Li, Z.; Ma, X.; Cui, X.; Chi, X.; Xu, W.; Hu, S. Sunflower seed oil containing ginseng stem-leaf saponins (E515-D) is a safe adjuvant for Newcastle disease vaccine. Poult. Sci. 2020, 99, 4795-4803. [CrossRef] [PubMed]

84. Ma, X.; Chi, X.; Yuan, L.; Wang, Y.; Li, Z.; Xu, W.; Rajput, Z.I.; Hu, S. Immunomodulatory effect of ginseng stem-leaf saponins and selenium on Harderian gland in immunization of chickens to Newcastle disease vaccine. Vet. Immunol. Immunopathol. 2020, 225, 110061. [CrossRef] [PubMed]

85. Liu, Y.; Shen, C.; He, Z.; Wei, C.; Su, N. Literature Analysis of the Efficacy of Arbidol in Virus Infectious Diseases. Biointerface Res. Appl. Chem. 2020, 11, 7646-7658. [CrossRef]

86. Sarkar, I.; Zardini Buzatto, A.; Garg, R.; Li, L.; Van Drunen Littel-Van Den Hurk, S. Metabolomic and Immunological Profiling of Respiratory Syncytial Virus Infection after Intranasal Immunization with a Subunit Vaccine Candidate. J. Proteome Res. 2019, 18, 1145-1161. [CrossRef]

87. Xing, Y.; Proesmans, M. New therapies for acute RSV infections: Where are we? Eur. J. Pediatr. 2019, 178, 131-138. [CrossRef]

88. Taleb, S.A.; Al Thani, A.A.; Al Ansari, K.; Yassine, H.M. Human respiratory syncytial virus: Pathogenesis, immune responses, and current vaccine approaches. Eur. J. Clin. Microbiol. Infect. Dis. 2018, 37, 1817-1827. [CrossRef] [PubMed]

89. Biswas, S.; Friedland, J.S.; Remick, D.G.; Davies, E.G.; Sharland, M. Elevated Plasma Interleukin 8 in Respiratory Syncytial Virus Bronchiolitis. Pediatr. Infect. Dis. J. 1995, 14, 919. [CrossRef]

90. Lee, J.S.; Hwang, H.S.; Ko, E.J.; Lee, Y.N.; Kwon, Y.M.; Kim, M.C.; Kang, S.M. Immunomodulatory activity of red ginseng against influenza a virus infection. Nutrients 2014, 6, 517-529. [CrossRef] [PubMed] 
91. Blanco, J.C.G.; Richardson, J.Y.; Darnell, M.E.R.; Rowzee, A.; Pletneva, L.; Porter, D.D.; Prince, G.A. Cytokine and chemokine gene expression after primary and secondary respiratory syncytial virus infection in cotton rats. J. Infect. Dis. 2002, 185, $1780-1785$. [CrossRef]

92. Zhang, Y.; Luxon, B.A.; Casola, A.; Garofalo, R.P.; Jamaluddin, M.; Brasier, A.R. Expression of Respiratory Syncytial Virus-Induced Chemokine Gene Networks in Lower Airway Epithelial Cells Revealed by cDNA Microarrays. J. Virol. 2001, 75, 9044-9058 [CrossRef] [PubMed]

93. Qu, D.F.; Yu, H.J.; Liu, Z.; Zhang, D.F.; Zhou, Q.J.; Zhang, H.L.; Du, A.F. Ginsenoside Rg1 enhances immune response induced by recombinant Toxoplasma gondii SAG1 antigen. Vet. Parasitol. 2011, 179, 28-34. [CrossRef]

94. Li, L.C.; Piao, H.M.; Zheng, M.Y.; Lin, Z.H.; Choi, Y.H.; Yan, G.H. Ginsenoside Rh2 attenuates allergic airway inflammation by modulating nuclear factor-KB activation in a murine model of asthma. Mol. Med. Rep. 2015, 12, 6946-6954. [CrossRef] [PubMed]

95. Shin, Y.M.; Jung, H.J.; Choi, W.Y.; Lim, C.J. Antioxidative, anti-inflammatory, and matrix metalloproteinase inhibitory activities of 20(S)-ginsenoside Rg3 in cultured mammalian cell lines. Mol. Biol. Rep. 2013, 40, 269-279. [CrossRef]

96. Jung, I.D.; Kim, H.Y.; Park, J.W.; Lee, C.M.; Noh, K.T.; Kang, H.K.; Heo, D.R.; Lee, S.J.; Son, K.H.; Park, H.J.; et al. RG-II from Panax ginseng C.A. Meyer suppresses asthmatic reaction. BMB Rep. 2012, 45, 79-84. [CrossRef]

97. Van der Heide, S.L.; Xi, Y.; Upham, J.W. Natural Killer Cells and Host Defense Against Human Rhinoviruses Is Partially Dependent on Type I IFN Signaling. Front. Cell. Infect. Microbiol. 2020, 10. [CrossRef]

98. Zhu, J.; Message, S.D.; Qiu, Y.; Mallia, P.; Kebadze, T.; Contoli, M.; Ward, C.K.; Barnathan, E.S.; Mascelli, M.A.; Kon, O.M.; et al. Airway inflammation and illness severity in response to experimental rhinovirus infection in asthma. Chest 2014, 145, 1219-1229. [CrossRef]

99. Im, K.; Kim, J.; Min, H. Ginseng, the natural effectual antiviral: Protective effects of Korean red ginseng against viral infection. J. Ginseng Res. 2016, 40, 309-314. [CrossRef]

100. Arden, K.E.; McErlean, P.; Nissen, M.D.; Sloots, T.P.; Mackay, I.M. Frequent detection of human rhinoviruses, paramyxoviruses, coronaviruses, and bocavirus during acute respiratory tract infections. J. Med. Virol. 2006, 78, 1232-1240. [CrossRef] [PubMed]

101. Kim, K.; An, J.M.; Jung, J.H.; Kang, I.G.; Choi, Y.S.; Kim, S.T. Korean red ginseng attenuates rhinovirus-stimulated IL-8, IL-6 responses in human nasal epithelial cells. Int. J. Clin. Exp. Med. 2017, 10, 1567-1574.

102. Wahab, S.; Ahmad, I.; Irfan, S.; Baig, M.H.; Farouk, A.-E.; Dong, J.-J. Use of Natural Compounds as a Potential Therapeutic Agent Against COVID-19. Curr. Pharm. Des. 2021, 27, 1144-1152. [CrossRef]

103. Wahab, S.; Ahmad, M.F.; Hussain, A.; Usmani, S.; Shoaib, A.; Ahmad, W. Effectiveness of Azithromycin as add-on Therapy in COVID-19 Management. Mini-Rev. Med. Chem. 2021, 21. [CrossRef]

104. Wahab, S.; Ahmad, I.; Usmani, S.; Ahmad, M.P. Epidemiological Situation and Efficacy of Dexamethasone for the treatment planning of COVID-19: A perspective review. Curr. Drug Deliv. 2020, 17. [CrossRef]

105. Rothan, H.A.; Byrareddy, S.N. The epidemiology and pathogenesis of coronavirus disease (COVID-19) outbreak. J. Autoimmun. 2020, 109, 102433. [CrossRef] [PubMed]

106. Fang, B.; Zhang, W.; Wu, X.; Huang, T.; Li, H.; Zheng, Y.; Che, J.; Sun, S.; Jiang, C.; Zhou, S.; et al. Shenhuang granule in the treatment of severe coronavirus disease 2019 (COVID-19): Study protocol for an open-label randomized controlled clinical trial. Trials 2020, 21, 568. [CrossRef] [PubMed]

107. Jalali, A.; Dabaghian, F.; Akbrialiabad, H.; Foroughinia, F.; Zarshenas, M.M. A pharmacology-based comprehensive review on medicinal plants and phytoactive constituents possibly effective in the management of COVID -19. Phyther. Res. 2020, 1925-1938. [CrossRef] [PubMed]

108. Leung, K.W.; Leung, F.P.; Mak, N.K.; Tombran-Tink, J.; Huang, Y.; Wong, R.N. Protopanaxadiol and protopanaxatriol bind to glucocorticoid and oestrogen receptors in endothelial cells. Br. J. Pharmcol. 2009, 156, 626-637. [CrossRef] [PubMed]

109. Mohanan, P.; Subramaniyam, S.; Mathiyalagan, R.; Yang, D.C. Molecular signaling of ginsenosides Rb1, Rg1, and Rg3 and their mode of actions. J. Ginseng Res. 2018, 42, 123-132. [CrossRef] [PubMed]

110. Zhang, B.; Zhou, W.-J.; Gu, C.-J.; Wu, K.; Yang, H.-L.; Mei, J.; Yu, J.-J.; Hou, X.-F.; Sun, J.-S.; Xu, F.-Y.; et al. The ginsenoside PPD exerts anti-endometriosis effects by suppressing estrogen receptor-mediated inhibition of endometrial stromal cell autophagy and NK cell cytotoxicity. Cell Death Dis. 2018, 9, 574. [CrossRef]

111. Strehlow, K.; Rotter, S.; Wassmann, S.; Adam, O.; Grohé, C.; Laufs, K.; Böhm, M.; Nickenig, G. Modulation of antioxidant enzyme expression and function by estrogen. Circ. Res. 2003, 93, 170-177. [CrossRef] [PubMed]

112. Pizzino, G.; Irrera, N.; Cucinotta, M.; Pallio, G.; Mannino, F.; Arcoraci, V.; Squadrito, F.; Altavilla, D.; Bitto, A. Oxidative Stress: Harms and Benefits for Human Health. Oxid. Med. Cell. Longev. 2017, 2017, 8416763. [CrossRef]

113. Nita, M.; Grzybowski, A. The Role of the Reactive Oxygen Species and Oxidative Stress in the Pathomechanism of the Age-Related Ocular Diseases and Other Pathologies of the Anterior and Posterior Eye Segments in Adults. Oxid. Med. Cell. Longev. 2016, 2016, 3164734. [CrossRef]

114. Szczuka, D.; Nowak, A.; Zakłos-Szyda, M.; Kochan, E.; Szymańska, G.; Motyl, I.; Blasiak, J. American ginseng (Panax quinquefolium L.) as a source of bioactive phytochemicals with pro-health properties. Nutrients 2019, 11, 1041. [CrossRef]

115. McElhaney, J.E.; Gravenstein, S.; Cole, S.K.; Davidson, E.; O’Neill, D.; Petitjean, S.; Rumble, B.; Shan, J.J. A Placebo-Controlled Trial of a Proprietary Extract of North American Ginseng (CVT-E002) to Prevent Acute Respiratory Illness in Institutionalized Older Adults. J. Am. Geriatr. Soc. 2004, 52, 13-19. [CrossRef] 
116. Predy, G.N.; Goel, V.; Lovlin, R.; Donner, A.; Stitt, L.; Basu, T.K. Efficacy of an extract of North American ginseng containing poly-furanosyl-pyranosyl-saccharides for preventing upper respiratory tract infections: A randomized controlled trial. CMAJ 2005, 173, 1043-1048. [CrossRef] [PubMed]

117. McElhaney, J.E.; Goel, V.; Toane, B.; Hooten, J.; Shan, J.J. Efficacy of COLD-fX in the prevention of respiratory symptoms in community-dwelling adults: A randomized, double-blinded, placebo controlled trial. J. Altern. Complement. Med. 2006, 12, 153-157. [CrossRef]

118. Zhou, P.; Lu, S.; Luo, Y.; Wang, S.; Yang, K.; Zhai, Y.; Sun, G.; Sun, X. Attenuation of TNF- $\alpha$-induced inflammatory injury in endothelial cells by ginsenoside Rb1 via inhibiting NF-кB, JNK and p38 signaling pathways. Front. Pharmcol. 2017, 8, 464. [CrossRef]

119. Kim, J.H.; Yi, Y.S.; Kim, M.Y.; Cho, J.Y. Role of ginsenosides, the main active components of Panax ginseng, in inflammatory responses and diseases. J. Ginseng Res. 2017, 41, 435-443. [CrossRef]

120. Soares, D.D.; Coimbra, C.C.; Marubayashi, U. Tryptophan-induced central fatigue in exercising rats is related to serotonin content in preoptic area. Neurosci. Lett. 2007, 415, 274-278. [CrossRef]

121. Yang, X.; Lv, Y.; Tian, L.; Zhao, Y. Composition and systemic immune activity of the polysaccharides from an herbal tea (lycopus lucidus turcz). J. Agric. Food Chem. 2010, 58, 6075-6080. [CrossRef]

122. Lee, C.S.; Lee, J.H.; Oh, M.; Choi, K.M.; Jeong, M.R.; Park, J.D.; Kwon, D.Y.; Ha, K.C.; Park, E.O.; Lee, N.; et al. Preventive effect of korean red ginseng for acute respiratory illness: A randomized and double-blind clinical trial. J. Korean Med. Sci. 2012, 27, 1472-1478. [CrossRef] [PubMed]

123. Lee, W.S.; Rhee, D.K. Corona-Cov-2 (COVID-19) and ginseng: Comparison of possible use in COVID-19 and influenza. J. Ginseng Res. 2021. [CrossRef] [PubMed]

124. Balkrishna, A.; POKHREL, S.; Singh, J.; Varshney, A. Withanone from Withania somnifera May Inhibit Novel Coronavirus (COVID19) Entry by Disrupting Interactions between Viral S-Protein Receptor Binding Domain and Host ACE2 Receptor. Res. Sq. 2020. [CrossRef]

125. Tripathi, M.K.; Singh, P.; Sharma, S.; Singh, T.P.; Ethayathulla, A.S.; Kaur, P. Identification of bioactive molecule from Withania somnifera (Ashwagandha) as SARS-CoV-2 main protease inhibitor. J. Biomol. Struct. Dyn. 2020, 1-14. [CrossRef]

126. Lu, C.C.; Chen, M.Y.; Lee, W.S.; Chang, Y.L. Potential therapeutic agents against COVID-19: What we know so far. J. Chin. Med. Assoc. 2020, 83, 534-536. [CrossRef]

127. Kumar, V.; Dhanjal, J.K.; Kaul, S.C.; Wadhwa, R.; Sundar, D. Withanone and caffeic acid phenethyl ester are predicted to interact with main protease (Mpro) of SARS-CoV-2 and inhibit its activity. J. Biomol. Struct. Dyn. 2020, 1-13. [CrossRef]

128. Tandon, N.; Yadav, S.S. Safety and clinical effectiveness of Withania Somnifera (Linn.) Dunal root in human ailments. J. Ethnopharmacol. 2020, 255, 112768. [CrossRef]

129. Mandlik, D.S.; Namdeo, A.G. Pharmacological evaluation of Ashwagandha highlighting its healthcare claims, safety, and toxicity aspects. J. Diet. Suppl. 2021, 18, 183-226. [CrossRef] [PubMed]

130. Ashwagandha the New HCQ? Modi Govt Begins Study to See If Herb Keeps Coronavirus Away. Available online: https: / / theprint.in/health/ashwagandha-the-new-hcq-modi-govt-begins-study-to-see-if-herb-keeps-coronavirus-away / 421830 / (accessed on 28 June 2021).

131. Saggam, A.; Limgaokar, K.; Borse, S.; Chavan-Gautam, P.; Dixit, S.; Tillu, G.; Patwardhan, B. Withania somnifera (L.) Dunal: Opportunity for Clinical Repurposing in COVID-19 Management. Front. Pharmcol. 2021, 12, 835.

132. Fallah, M.S.; Bayati, M.; Najafi, A.; Behmard, E.; Davarpanah, S.J. Molecular docking investigation of antiviral herbal compounds as potential inhibitors of sars-cov-2 spike receptor. Biointerface Res. Appl. Chem. 2021, 11, 12916-12924. [CrossRef]

133. Chikhale, R.V.; Gurav, S.S.; Patil, R.B.; Sinha, S.K.; Prasad, S.K.; Shakya, A.; Shrivastava, S.K.; Gurav, N.S.; Prasad, R.S. Sars-cov-2 host entry and replication inhibitors from Indian ginseng: An in-silico approach. J. Biomol. Struct. Dyn. 2020. [CrossRef] [PubMed]

134. Hetrick, B.; Yu, D.; Olanrewaju, A.A.; Chilin, L.D.; He, S.; Dabbagh, D.; Alluhaibi, G.; Ma, Y.-C.; Hofmann, L.A.; Hakami, R.M.; et al. A traditional medicine, respiratory detox shot (RDS), inhibits the infection of SARS-CoV, SARS-CoV-2, and the influenza A virus in vitro. Cell Biosci. 2021, 11, 100. [CrossRef]

135. Zhai, L.; Li, Y.; Wang, W.; Wang, Y.; Hu, S. Effect of oral administration of ginseng stem-and-leaf saponins (GSLS) on the immune responses to Newcastle disease vaccine in chickens. Vaccine 2011, 29, 5007-5014. [CrossRef]

136. Yin, S.Y.; Kim, H.J.H.J.; Kim, H.J.H.J. A comparative study of the effects of whole red ginseng extract and polysaccharide and saponin fractions on influenza A (H1N1) virus infection. Biol. Pharm. Bull. 2013, 36, 1002-1007. [CrossRef]

137. Yoo, D.G.; Kim, M.C.; Park, M.K.; Song, J.M.; Quan, F.S.; Park, K.M.; Cho, Y.K.; Kang, S.M. Protective effect of korean red ginseng extract on the infections by H1N1 and H3N2 influenza viruses in mice. J. Med. Food 2012, 15, 855-862. [CrossRef]

138. Yoo, D.-G.G.; Kim, M.-C.C.; Park, M.-K.K.; Park, K.-M.M.; Quan, F.-S.S.; Song, J.-M.M.; Wee, J.J.; Wang, B.-Z.Z.; Cho, Y.-K.K.; Compans, R.W.; et al. Protective Effect of Ginseng Polysaccharides on Influenza Viral Infection. PLoS ONE 2012, 7, e33678. [CrossRef]

139. Kim, E.H.; Kim, S.W.; Park, S.J.; Kim, S.; Yu, K.M.; Kim, S.G.; Lee, S.H.; Seo, Y.K.; Cho, N.H.; Kang, K.; et al. Greater efficacy of black ginseng (CJ enerG) over red ginseng against lethal influenza a virus infection. Nutrients 2019, 11, 1879. [CrossRef] [PubMed] 
140. Lee, J.S.; Cho, M.K.; Hwang, H.S.; Ko, E.-J.; Lee, Y.-N.; Kwon, Y.-M.; Kim, M.-C.; Kim, K.-H.; Lee, Y.-T.; Jung, Y.-J.; et al. Ginseng diminishes lung disease in mice immunized with formalin-inactivated respiratory syncytial virus after challenge by modulating host immune responses. J. Interferon Cytokine Res. 2014, 34, 902-914. [CrossRef] [PubMed]

141. Lee, J.S.; Ko, E.J.; Hwang, H.S.; Lee, Y.N.; Kwon, Y.M.; Kim, M.C.; Kang, S.M. Antiviral activity of ginseng extract against respiratory syncytial virus infection. Int. J. Mol. Med. 2014, 34, 183-190. [CrossRef]

142. Song, J.H.; Choi, H.J.; Song, H.H.; Hong, E.H.; Lee, B.R.; Oh, S.R.; Choi, K.; Yeo, S.G.; Lee, Y.P.; Cho, S.; et al. Antiviral activity of ginsenosides against coxsackievirus B3, enterovirus 71, and human rhinovirus 3. J. Ginseng Res. 2014, 38, 173-179. [CrossRef] [PubMed]

143. Cai, Z.; Zhang, G.; Tang, B.; Liu, Y.; Fu, X.; Zhang, X. Promising Anti-influenza Properties of Active Constituent of Withania somnifera Ayurvedic Herb in Targeting Neuraminidase of H1N1 Influenza: Computational Study. Cell Biochem. Biophys. 2015, 72, 727-739. [CrossRef] [PubMed]

144. Blair, J.M.A.; Webber, M.A.; Baylay, A.J.; Ogbolu, D.O.; Piddock, L.J. V Molecular mechanisms of antibiotic resistance. Nat. Rev. Microbiol. 2015, 13, 42-51. [CrossRef] [PubMed]

145. Pizarro-Cerdá, J.; Cossart, P. Bacterial adhesion and entry into host cells. Cell 2006, 124, 715-727. [CrossRef] [PubMed]

146. Kim, Y.R.; Yang, C.S. Protective roles of ginseng against bacterial infection. Microb. Cell 2018, 5, 472-481. [CrossRef]

147. Kim, G.; Kim, T.H.; Kang, M.J.; Choi, J.A.; Pack, D.Y.; Lee, I.R.; Kim, M.G.; Han, S.S.; Kim, B.Y.; Oh, S.M.; et al. Inhibitory effect of withaferin A on Helicobacter pylori-induced IL-8 production and NF- $\mathrm{kB}$ activation in gastric epithelial cells. Mol. Med. Rep. 2016, 13, 967-972. [CrossRef]

148. Owais, M.; Sharad, K.S.; Shehbaz, A.; Saleemuddin, M. Antibacterial efficacy of Withania somnifera (ashwagandha) an indigenous medicinal plant against experimental murine salmonellosis. Phytomedicine 2005, 12, 229-235. [CrossRef]

149. Arora, S.; Dhillon, S.; Rani, G.; Nagpal, A. The in vitro antibacterial/synergistic activities of Withania somnifera extracts. Fitoterapia 2004, 75, 385-388. [CrossRef]

150. Sundaram, S.; Dwivedi, P.; Purwar, S. In vitro Evaluation of Antibacterial Activities of Crude Extracts of Withania somnifera (Ashwagandha) to Bacterial Pathogens. Asian J. Biotechnol. 2011, 3, 194-199. [CrossRef]

151. Lee, J.H.; Eun, K.P.; Uhm, C.S.; Chung, M.S.; Kyung, H.K. Inhibition of Helicobacter pylori adhesion to human gastric adenocarcinoma epithelial cells by acidic polysaccharides from Artemisia capillaris and Panax ginseng. Planta Med. 2004, 70, 615-619. [CrossRef] [PubMed]

152. Yang, J.W.; Choi, S.Y.; Park, S.J.; Paek, N.S.; Kim, S.S. Anti-Helicobacter Pylori effect of fermented ginseng extracts with Lactobacillus plantarum MG 208. J. Korean Soc. Appl. Biol. Chem. 2012, 55, 53-56. [CrossRef]

153. Park, S.; Yeo, M.; Jin, J.H.; Lee, K.M.; Jung, J.Y.; Choue, R.; Sung, W.C.; Hahm, K.B. Rescue of Helicobacter pylori-Induced cytotoxicity by red ginseng. Dig. Dis. Sci. 2005, 50, 1218-1227. [CrossRef] [PubMed]

154. Jee, H.-S.; Chang, K.-H.; Moon, S.-H.; Park, S.-H.; Paik, H.-D. Anti-Helicobacter pylori, Cytotoxic, and Anti-inflammatory Activities of White Ginseng Extract. Food Sci. Biotechnol. 2008, 17, 1106-1109.

155. Wu, H.; Lee, B.; Yang, L.; Wang, H.; Givskov, M.; Molin, S.; Høiby, N.; Song, Z. Effects of ginseng on Pseudomonas aeruginosa motility and biofilm formation. FEMS Immunol. Med. Microbiol. 2011, 62, 49-56. [CrossRef]

156. Song, Z.; Moser, C.; Wu, H.; Faber, V.; Kharazmi, A.; Høiby, N. Cytokine modulating effect of ginseng treatment in a mouse model of Pseudomonas aeruginosa lung infection. J. Cyst. Fibros. 2003, 2, 112-119. [CrossRef]

157. Lim, D.S.; Bae, K.G.; Jung, I.S.; Kim, C.H.; Yun, Y.S.; Song, J.Y. Anti-septicaemic effect of polysaccharide from Panax ginseng by macrophage activation. J. Infect. 2002, 45, 32-38. [CrossRef]

158. Ahn, J.-Y.; Choi, I.-S.; Shim, J.-Y.; Yun, E.-K.; Yun, Y.-S.; Jeong, G.; Song, J.-Y. The immunomodulator ginsan induces resistance to experimental sepsis by inhibiting Toll-like receptor-mediated inflammatory signals. Eur. J. Immunol. 2006, 36, 37-45. [CrossRef]

159. Sung, W.S.; Lee, D.G. The combination effect of Korean red ginseng saponins with kanamycin and cefotaxime against methicillinresistant Staphylococcus aureus. Biol. Pharm. Bull. 2008, 31, 1614-1617. [CrossRef] [PubMed]

160. Xue, P.; Yao, Y.; Yang, X.S.; Feng, J.; Ren, G.X. Improved antimicrobial effect of ginseng extract by heat transformation. J. Ginseng Res. 2017, 41, 180-187. [CrossRef] [PubMed]

161. Lee, J.H.; Shim, J.S.; Lee, J.S.; Kim, M.K.; Chung, M.S.; Kim, K.H. Pectin-like acidic polysaccharide from Panax ginseng with selective antiadhesive activity against pathogenic bacteria. Carbohydr. Res. 2006, 341, 1154-1163. [CrossRef] [PubMed]

162. Choi, Y.H.; Kim, S.E.; Huh, J.; Han, Y.H.; Lee, M.J. Antibacterial and antioxidative activity of roasted coffee and red ginseng mixture extracts. J. Korean Soc. Food Sci. Nutr. 2012, 41, 320-326. [CrossRef]

163. Pseudomonas aeruginosa Infection I HAI I CDC. Available online: https://www.cdc.gov/hai/organisms/pseudomonas.html (accessed on 29 January 2021).

164. Song, Z.; Kharazmi, A.; Wu, H.; Faber, V.; Moser, C.; Johansen, H.K.; Rygaard, J.; Høiby, N. Effects of ginseng treatment on neutrophil chemiluminescence and immunoglobulin $\mathrm{G}$ subclasses in a rat model of chronic Pseudomonas aeruginosa pneumonia. Clin. Diagn. Lab. Immunol. 1998, 5, 882-887. [CrossRef]

165. Alipour, M.; Omri, A.; Suntres, Z.E. Ginseng aqueous extract attenuates the production of virulence factors, stimulates twitching and adhesion, and eradicates biofilms of Pseudomonas aeruginosa. Can. J. Physiol. Pharmcol. 2011, 89, 419-427. [CrossRef]

166. Song, Z.; Kong, K.F.; Wu, H.; Maricic, N.; Ramalingam, B.; Priestap, H.; Schneper, L.; Quirke, J.M.E.; Høiby, N.; Mathee, K. Panax ginseng has anti-infective activity against opportunistic pathogen Pseudomonas aeruginosa by inhibiting quorum sensing, a bacterial communication process critical for establishing infection. Phytomedicine 2010, 17, 1040-1046. [CrossRef] 
167. Horsley, A. Book review: Hodson and Geddes' Cystic Fibrosis. Breathe 2016, 12, 91-92. [CrossRef]

168. Ramsey, D.M.; Wozniak, D.J. Understanding the control of Pseudomonas aeruginosa alginate synthesis and the prospects for management of chronic infections in cystic fibrosis. Mol. Microbiol. 2005, 56, 309-322. [CrossRef]

169. Song, Z.; Johansen, H.K.; Faber, V.; Moser, C.; Kharazmi, A.; Rygaard, J.; Høiby, N. Ginseng treatment reduces bacterial load and lung pathology in chronic Pseudomonas aeruginosa pneumonia in rats. Antimicrob. Agents Chemother. 1997, 41, 961-964. [CrossRef]

170. Lee, S.O.; Lee, S.; Kim, S.J.; Rhee, D.K. Korean Red Ginseng enhances pneumococcal $\Delta$ pep27 vaccine efficacy by inhibiting reactive oxygen species production. J. Ginseng Res. 2019, 43, 218-225. [CrossRef]

171. Ahmed, A.B.M. Microbial toxinology for safer drug industry. J. Pharm. Care Health Syst. 2016, 03, 4. [CrossRef]

172. Nguyen, C.T.; Luong, T.T.; Lee, S.Y.; Kim, G.L.; Kwon, H.; Lee, H.G.; Park, C.K.; Rhee, D.K. Panax ginseng aqueous extract prevents pneumococcal sepsis in vivo by potentiating cell survival and diminishing inflammation. Phytomedicine 2015, 22, 1055-1061. [CrossRef]

173. Ha, K.C.; Kim, M.G.; Oh, M.R.; Choi, E.K.; Back, H.I.; Kim, S.Y.; Park, E.O.; Kwon, D.Y.; Yang, H.J.; Kim, M.J.; et al. A placebocontrolled trial of Korean red ginseng extract for preventing Influenza-like illness in healthy adults. BMC Complement. Altern. Med. 2012, 12. [CrossRef] [PubMed]

174. McElhaney, J.E.; Simor, A.E.; McNeil, S.; Predy, G.N. Efficacy and Safety of CVT-E002, a Proprietary Extract of Panax quinquefolius in the Prevention of Respiratory Infections in Influenza-Vaccinated Community-Dwelling Adults: A Multicenter, Randomized, Double-Blind, and Placebo-Controlled Trial. Influenza Res. Treat. 2011, 2011, 1-8. [CrossRef]

175. Kuhle, S.; Seida, J.K.; Durec, T. North American (Panax quinquefolius) and Asian ginseng (Panax ginseng) preparations for prevention of the common cold in healthy adults: A systematic review. Evid.-Based Complement. Altern. Med. $2011,2011$. [CrossRef]

176. Vohra, S.; Johnston, B.C.; Laycock, K.L.; Midodzi, W.K.; Dhunnoo, I.; Harris, E.; Baydala, L. Safety and tolerability of north american ginseng extract in the treatment of pediatric upper respiratory tract infection: A phase II randomized, controlled trial of 2 dosing schedules. Pediatrics 2008, 122, e402-e410. [CrossRef] [PubMed]

177. Wu, L.; Zhang, A.L.; Di, Y.M.; Shergis, J.L.; Chen, Y.; Guo, X.; Wen, Z.; Thien, F.; Worsnop, C.; Lin, L.; et al. Panax ginseng therapy for chronic obstructive pulmonary disease: A clinical trial protocol and pilot study. Chin. Med. 2014, 9, 1-8. [CrossRef]

178. High, K.P.; Case, D.; Hurd, D.; Powell, B.; Lesser, G.; Falsey, A.R.; Siegel, R.; Metzner-Sadurski, J.; Krauss, J.C.; Chinnasami, B.; et al. A Randomized, Controlled Trial of Panax quinquefolius Extract (CVT-E002) to Reduce Respiratory Infection in Patients With Chronic Lymphocytic Leukemia. J. Support. Oncol. 2012, 10, 195-201. [CrossRef]

179. Hwang, J.H.; Park, S.H.; Choi, E.K.; Jung, S.J.; Pyo, M.K.; Chae, S.W. A randomized, double-blind, placebo-controlled pilot study to assess the effects of protopanaxadiol saponin-enriched ginseng extract and pectinase-processed ginseng extract on the prevention of acute respiratory illness in healthy people. J. Ginseng Res. 2020, 44, 697-703. [CrossRef]

180. Wang, M.; Guilbert, L.J.; Ling, L.; Li, J.; Wu, Y.; Xu, S.; Pang, P.; Shan, J.J. Immunomodulating activity of CVT-E002, a proprietary extract from North American ginseng (Panax quinquefolium). J. Pharm. Pharmacol. 2001, 53, 53. [CrossRef] [PubMed]

181. Ernst, E. Panax ginseng: An Overview of the Clinical Evidence. J. Ginseng Res. 2010, 34, 259-263. [CrossRef] 